\title{
Fossil middle triassic "sea cows" - placodont reptiles as macroalgae feeders along the north-western Tethys coastline with Pangaea and in the Germanic basin
}

\author{
Cajus G. Diedrich
}

Paleologic, Nansenstr, Germany; cdiedri@gmx.net

Received 19 October 2010; revised 22 November 2010; accepted 27 November 2010.

\begin{abstract}
The descriptions of fossil Triassic marine placodonts as durophagous reptiles are revised through comparisons with the sirenia and basal proboscidean mammal and palaeoenvironment analyses. The jaws of placodonts are convergent with those of Halitherium/Dugong or Moeritherium in their general function. Whereas Halitherium possessed a horny oral pad and counterpart and a special rasp-like tongue to grind seagrass, as does the modern Dugong, placodonts had large teeth that covered their jaws to form a similar grinding pad. The sirenia also lost their anterior teeth during many Millions of years and built a horny pad instead and specialized tongue to fed mainly on seagrass, whereas placodonts had only macroalgae available. Indirect evidence for Triassic macroalgae is provided by benthic palaeocommunities from different layers and extended European regions in the Germanic Basin. Studies of tooth wear stages for Placodus indicate that anterior teeth may have been used in a similar manner to the procumbent front teeth of modern Dugong. Paraplacodus and Placodus seem to have used these teeth as spatulas to dig out seaplants. Cyamodus and other placodonts such as Placochelys had smaller or reduced anterior teeth. The scarcity of highly worn palatine or maxillary and lower jaw dentary Placodus or Cyamodus teeth (less then $0.5 \%$ ) suggests that they had a relatively soft diet. The seaplants would only have been squeezed in a similar feeding strategy to that of modern Dugong feeding on seagrass without jaw rotation and grinding. The phylogenetic trend in tooth reduction within the placodonts Paraplacodus, Placodus, especially in Cyamodus but also Placochelys, and Henodus within $11 \mathrm{My}$ appears to have been a result of
\end{abstract}

this plant-feeding adaptation and may even explain the origin or at least close relationship of the earliest Upper Triassic turtles as toothless algae and jellyfish feeders, in terms of the long-term convergent development with the sirens.

Keywords: Placodont Reptiles; Triassic; Convergent Evolutionary Ecological Adaptation; Sirenia; Macroalgae Feeders; NW Tethys Shelf; Palaeoecology

\section{INTRODUCTION}

The extinct reptile group of the placodonts found in Germany and other European sites (Figure 1), a group of diverse marine diving reptiles, had large teeth covering the lower and complete upper jaws (Figsure 2-5) which made those reptiles quite unique within all known extinct and extant reptiles on Planet Earth. Those popular named "Triassic sea cows" [1] were found commonly with their bones and typical large teeth all over Europe mainly in the Germanic Basin of Central Europe [1-4]. Placodonts were later discovered additionally in the north-western Tethys of southern Europe [3,5-7], and were recorded only with few skeletons in the Middle Triassic in the eastern Tethys in China [8].

The historical first recorded placodont remains of the world are from Placodus (Figure 3) which were discovered in 1809 near Bayreuth (Bavaria, south Germany) at the northern Lainecker Höhenzug (Middle Triassic mountain chain) mainly due to the activities of Graf zu Münster [9], Agassiz [10] in more than six, today only partly remained quarries at Hegnabrunn, Bindlach and Laineck [11] which were recently restudied in the accessible sections and with their facies and bone taphonomy [13]. Placodus remains were first identified as a "large Triassic fish" [9], but subsequently named and recognized as a marine reptile $[10,12]$. Single teeth, bones and 


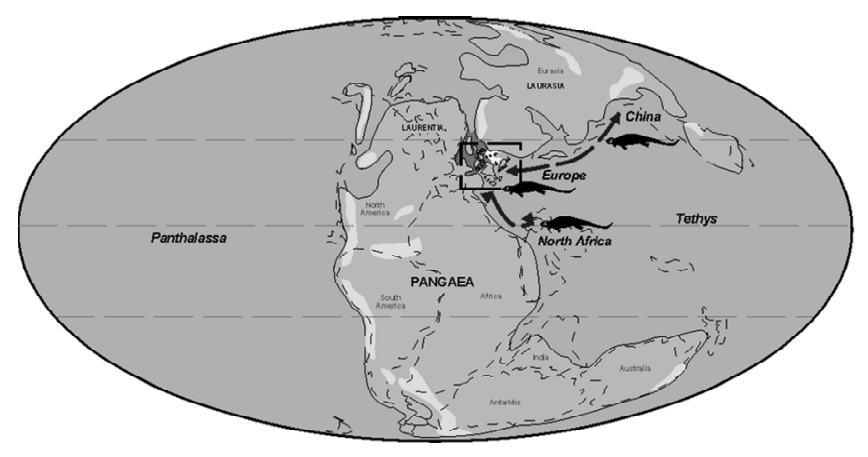

(a)

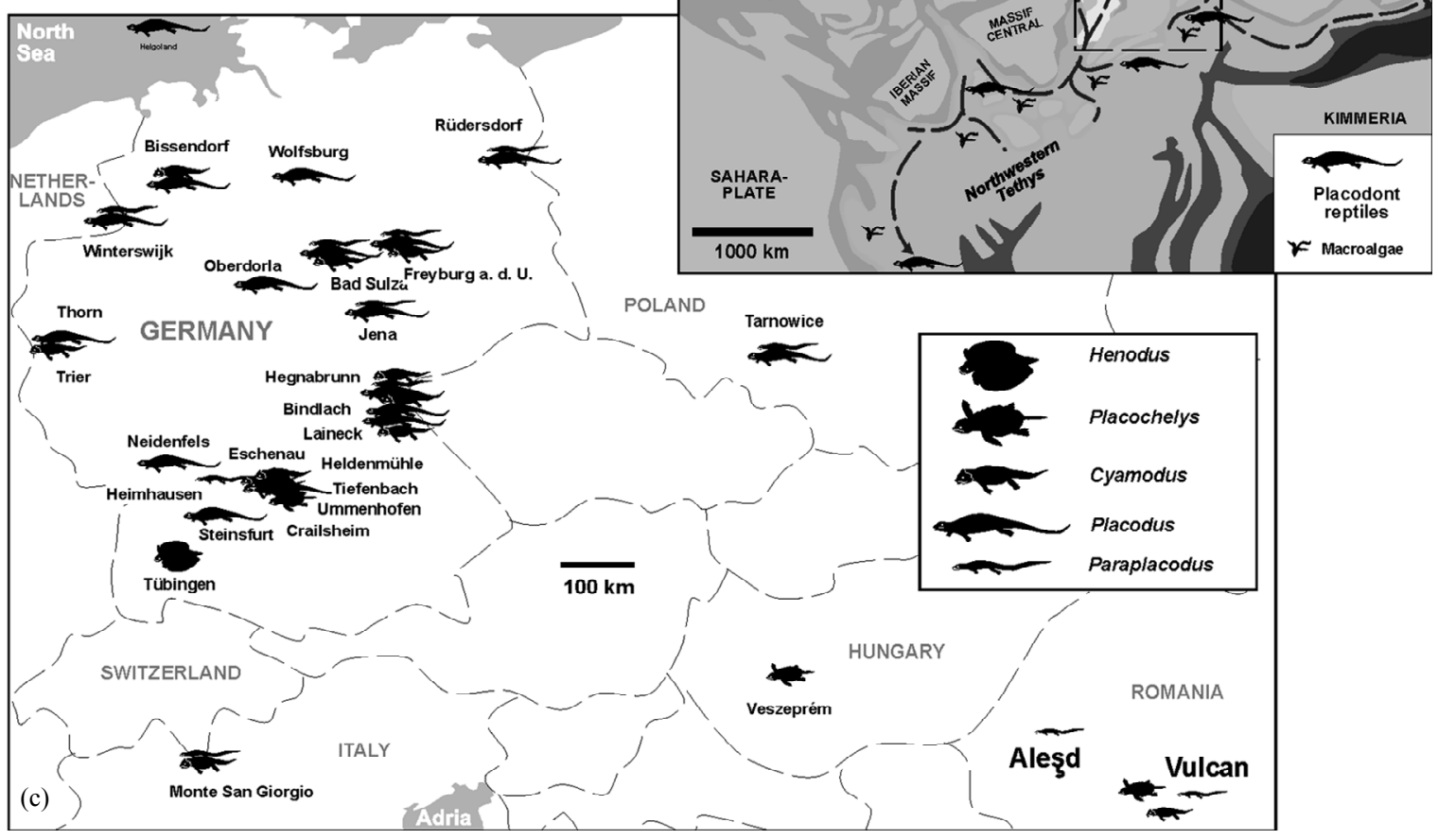

Figure 1. (a) Global distribution of Middle Triassic fossil placodont "sea cows" along the north-west Tethys (China, Europe, North-Africa). (b) Distribution in Central Europe correlating with macroalgae presence in shallow marine carbonate platform environments. (c) Middle Triassic marine placodont reptile bone and skeleton localities of Europe of which are most found in the "Muschelkalk limestones" of Germany.
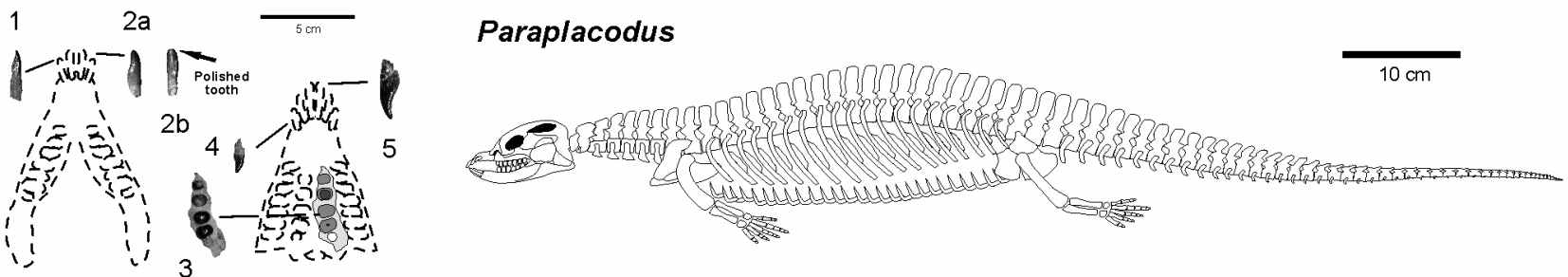

Figure 2. Paraplacodus cf. broilii Peyer, 1937 skull and tooth remains. 1. Lower jaw anterior tooth from the Jena Fm. (muS substage, Pelsonian) of Freyburg a. d. U., Germany (MB no. 4736), lateral. 2. Lower jaw anterior tooth from the Jena Fm. (muS substage, Pelsonian) of Jena, Germany (MLU.IfG no. 2007.26), a. lateral, b. lingual. 3. Palatinal with five teeth (one damaged) from the Upper Muschelkalk of Tarnowice, Poland (MB no. R. 4418), a-b. ventral. 4. Upper jaw premaxillary tooth from the Jena Fm. (muS substage, Pelsonian) of Heimhausen, Germany (MHI no. 1204), lateral. 5. Upper jaw premaxillary tooth from the Jena Fm. (muS substage, Pelsonian) of Freyburg a. d. U., Germany (MB no. R.4420), lateral. Skeleton reconstruction based on the skeleton from Monte San Giorgio (Switzerland). 


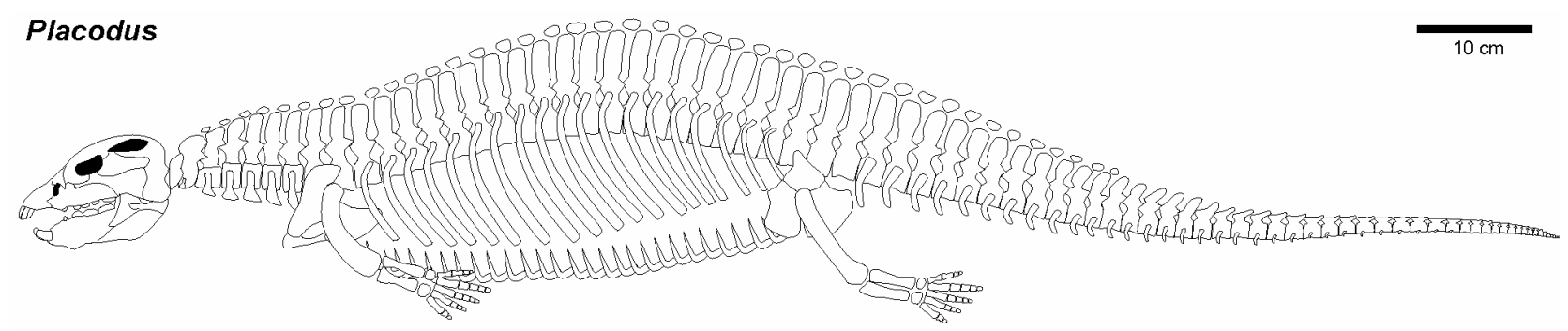

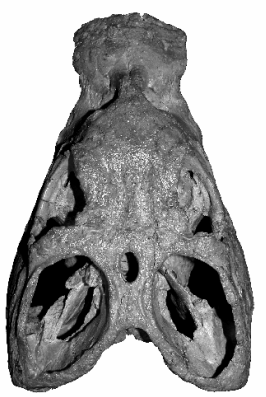

1a

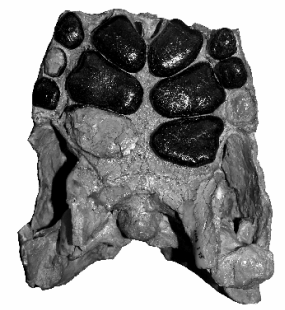

$3 a$

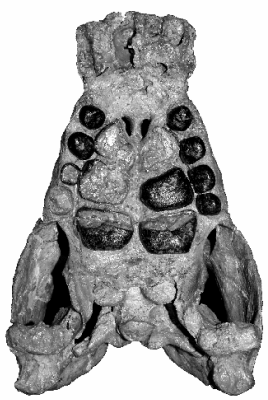

$1 b$

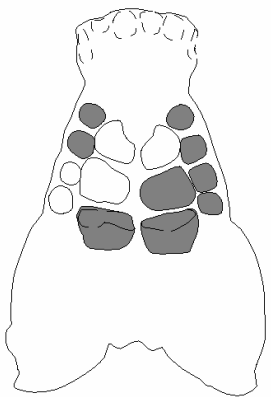

$1 \mathrm{c}$

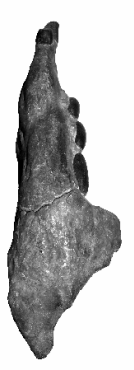

$2 c$
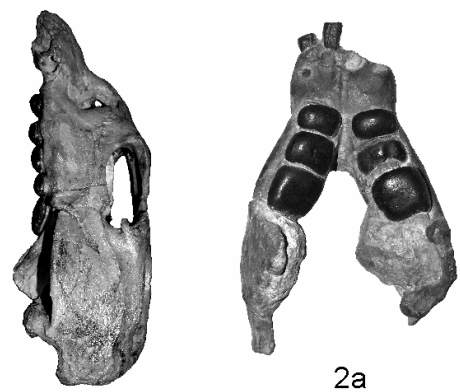

$2 a$

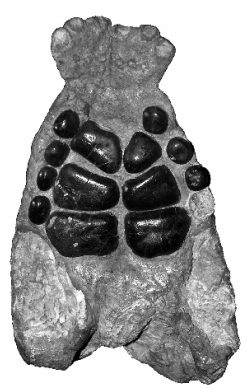

$4 a$

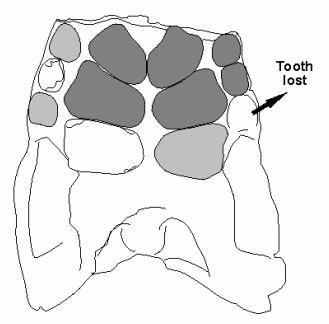

$3 b$

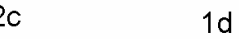

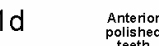

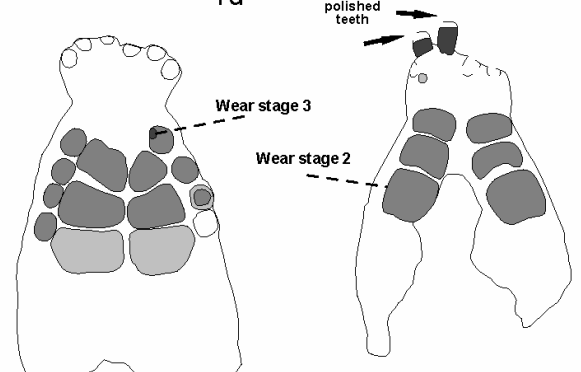

$2 b$

$4 b$

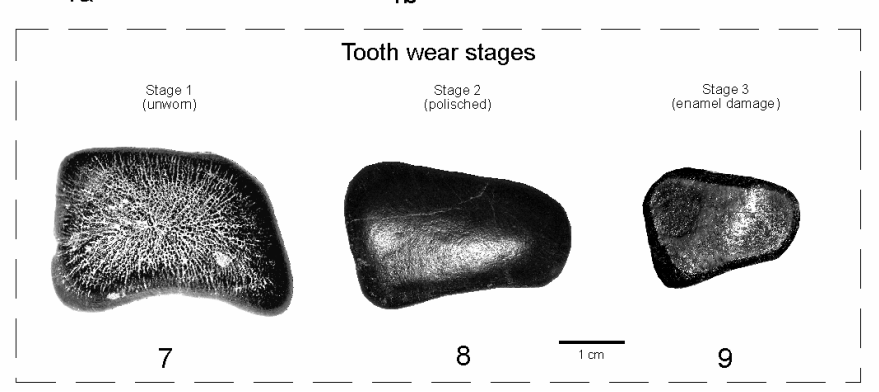

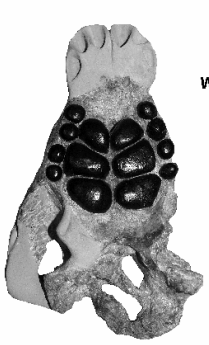

$5 a$

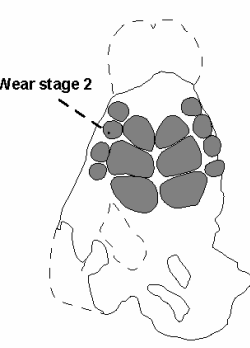

$5 b$

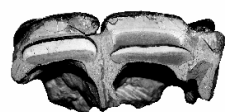

$6 a$

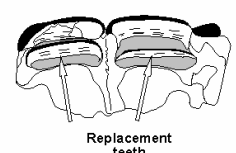

$6 b$
Replacement
teeth

Figure 3. Placodus gigas Agassiz, 1833 skulls, jaws and teeth from the "Upper Muschelkalk" (Anisian, Middle Triassic) from the Germanic Basin (Central Europe). 1. Skull of the Bindlach Fm. (Illyrian, Upper Anisian) from Bindlach (Lainecker Höhenzug), Germany (UM-O BT 13), ventral. 2. Lower jaw (cast) from the Bindlach Fm. (Illyrian, Upper Anisian) of Bindlach (Lainecker Höhenzug), Germany (UM-O no. BT 5067.00; original in the BSP no. 1209), a. dorsal, b. lateral. 3. Skull from the Hegnabrunn Fm. (Fassanian, Lower Ladinian) of Hegnabrunn, Germany (BSP no. 1968 I 75), a-b. ventral. 4. Skull from the Bindlach Fm. (Illyrian, Upper Anisian) of Bindlach (Lainecker Höhenzug), Germany (UM-O without no.), ventral. 5. Skull of a younger individual from the Bindlach Fm. (Illyrian, Upper Anisian) from Bindlach (Lainecker Höhenzug), Germany (SNSD without no.), ventral. 6. Cross-section through a skull palatinal from the Bindlach Fm. (Illyrian, Upper Anisian) of Bindlach (Lainecker Höhenzug), Germany (SBMF no. R.361). 7. Lower jaw dentary tooth in wear stage 1 with enamel structure from the Bindlach Fm. (Illyrian/Fassanian, Upper Anisian) of Laineck (Oschenberg, Lainecker Höhenzug), Germany (MB without no.). 8. Palatinal tooth in wear stage 2 with smooth surface from the Bindlach Fm. (Illyrian/Fassanian, Upper Anisian) of Bindlach or Laineck (Lainecker Höhenzug), Germany (NMB without no.), occlusal. 9. Palatinal tooth in wear stage 3 with rubbed enamel from the Bindlach Fm. (Illyrian/Fassanian, Upper Anisian) of Bindlach or Laineck (Lainecker Höhenzug), Germany (MB without no.), occlusal. Placodus skeleton reconstruction based on the skeleton from Steinsfurt (Germany). 
skulls of Placodus (Figsure 3.1-6) from the Middle Triassic were recorded mainly from Bindlach near Bayreuth in southern Germany with descriptions of many different today non-valid "species" [14-16], but also more recently from many other German and even Dutch localities $[4,5,9,10,17-23]$. The first and only European placodont skeleton of the world was discovered then much later with a skeleton of Placodus gigas Agassiz, 1839 at Steinsfurt (South Germany; [21]; Figure 5.5). Only a single Paraplacodus skeleton remain, the most rare in the Northern Tethys [7], is recorded most recently also with two more skeletons and isolated cranial remains from the Germanic Basin in Romania and the Netherlands [24,25]. The few Cyamodus holotype skulls (Figure 4) were collected by Münster from the Lainecker Höhenzug localities of Germany $[9,20,26]$, whereas more recent remains were found at other southern German localities $[27,28]$. Four recently valid species of Cyamodus (Figures 4.7-1.10) have been described: $C$. tarnowitzensis Gürich, 1884, C. rostratus Münster, 1839 (Figures 4.7-1.8), C. münsteri (Agassiz, 1839) (= "Placodus laticeps Owen, 1858") (Figure 4.4) and $C$. kuhnschnyderi Nosotti and Pinna, 1993 (Figures 4.9-1.10) from only a few crania [26], and C. hildegardis Peyer, 1931 from a skeletal remain in the northern Tethys at Monte San Giorgio [6] .

The systematic position of placodonts within the extinct sauropterygian reptiles have been discussed by several authors, mainly on the cranial morphology but not solely and most recently only in an cladistic way $[3,6$, 10,29-31] but recently initially in more biostratigraphic, taphonomic and ecological context [26]. Former interpretations $[3,27,32,33]$ described all placodonts as "shell crushing durophagous" reptiles, based solely on their "shell crushing tooth morphology" without taking into account any other considerations. Most recent studies have, however, now identified all placodonts as having been "macroalgae feeders" [1] which theory is presented here with much more material and extended arguments including all placodonts in time and space of the Middle Triassic Pangaean world in a time frame between 247-236 My (11 My in total).

\section{MATERIAL AND METHODS}

The new "Triassic sea cow" theories are based on interdisciplinary research about the 1) stratigraphic occurrence and historic and recent placodont discoveries and palaeobiogeography, 2) facies including palaeocommunities with evidence of macroalgae, 3) bone taphonomy, 4) osteological and functional morphology, 5) feeding strategy in comparison with modern Sirenia, and, 6) finally, types of placodont teeth and their tooth wear and replacement stages.
1) Stratigraphic occurrence of historic and recent placodont discoveries and palaeobiogeography: Several about 220 meters in thickness marine carbonate Middle Triassic "Muschelkalk" sections in the Germanic Basin, including the famous Winterswijk, Bayreuth, Freyburg a. d. U. and many other sites such as Bissendorf or Lamerden were subdivided more recently with the international subdivision for exact dating of the historical and new discovered skeleton finds and isolated bone material. The dating and correlation between Tethys and Germanic Basin deposits is essential for understanding the evolutionary trend within the studied 11 My ranging Middle Triasic "Lower/Middle/Upper Muschelkalk" placodont evolution and distribution. In this analyses most of the material was dated in more detail or even for the first time including famous holotype and original skulls or skeletons.

Paraplacodus is represented recently with a Longobardian aged skeleton from the Monte San Giorgio Illyrian lagoon black shale deposits. From the Germanic Basin the single bone and tooth record from is very limited with a part of a disarticulated skeleton known from Winterswijk (NL, Aegean age) and Brașov (Ro, Aegean age) which both do not include tooth material. Teeth are instead isolated finds from different sites in Germany (Figure 1) ranging between Pelsonian to Illyrian age, whereas a palatine from Tarnowice (Pl) is of Illyrian age (Figures 2.2-3).

Placodus instead is well-known starting with remains from the Aegean aged intertidal deposits of Winterswijk. Many isolated teeth and bones are from the shallow submarine carbonate sand bar sediments of Freyburg a. d. U. or Jena sites. Most material was found at the Illyrian aged shallow marine glauconite-rich carbonates of Bayreuth including the holotype and many other sulls and hundreds of teeth or single bones. The only world-wide record of a $P$. gigas skeleton from Steinsfurt (D) is also of Illyrian age (Figure 6.5).

Cyamodus is represented from the Monte San Giorgio with skeleton remains of Longobardian age, but in the Germanic Basin only few skulls were found first in historic times and from Illyrian, Fassanian and Longobardian dated marine shallow subtidal layers (Figure 4). Here a more detailed biostratigraphic occurrence can be presented after the Bayreuth Cyamodus locality studies including ceratite cephalopods, which prove a rapid cyamodontid evolution of the genus within the IllyrianLongobardian times. The oldest record of Aegean age of C. tarnowitzensis is followed by the Illyrian species of $C$. rostratus (atavus-compressus ceratie biozones, Upper Illyrian), by C. muensteri (evolutus-sublaevigatus ceratite biozones, Fassanian), and finally by $C$. kuhnschnyderi (praenodosus-semipartitus ceratite biozones, Longobardian). In total a tooth reduction and rostrum shortening 


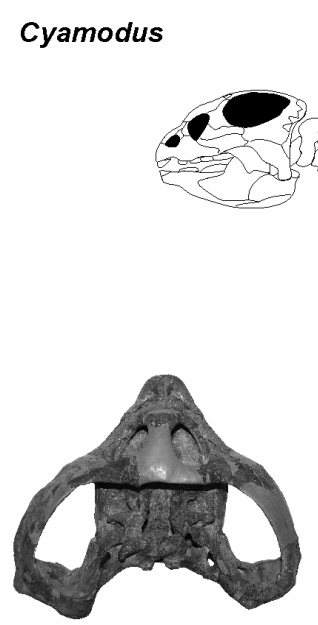

$6 a$

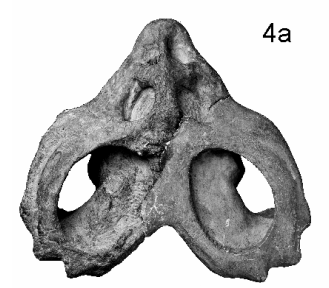

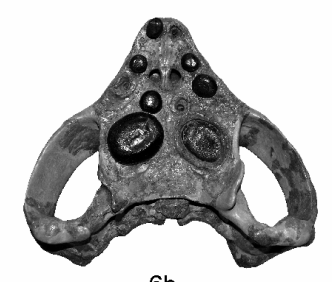

$6 b$

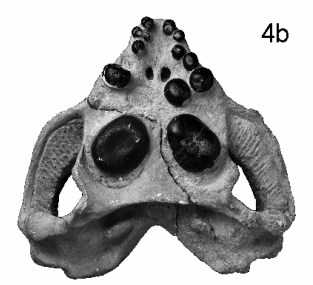

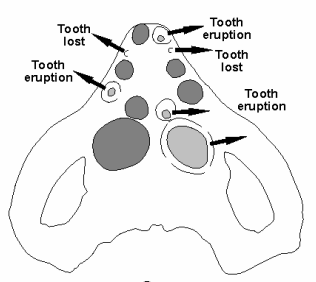

$6 c$

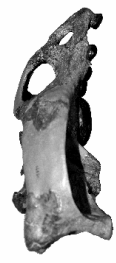

$6 d$
$7 a$
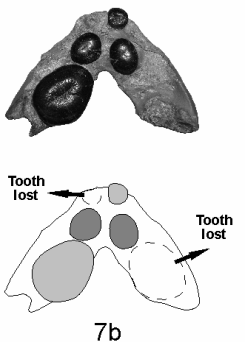
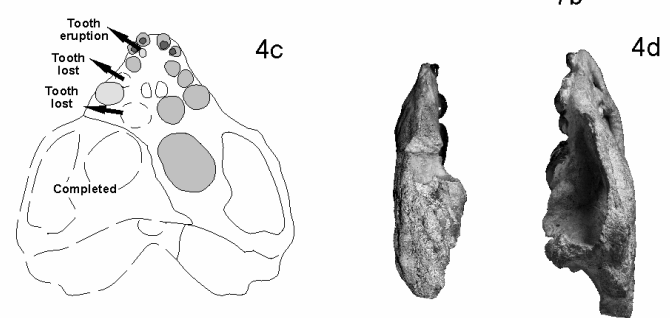

$5 c$
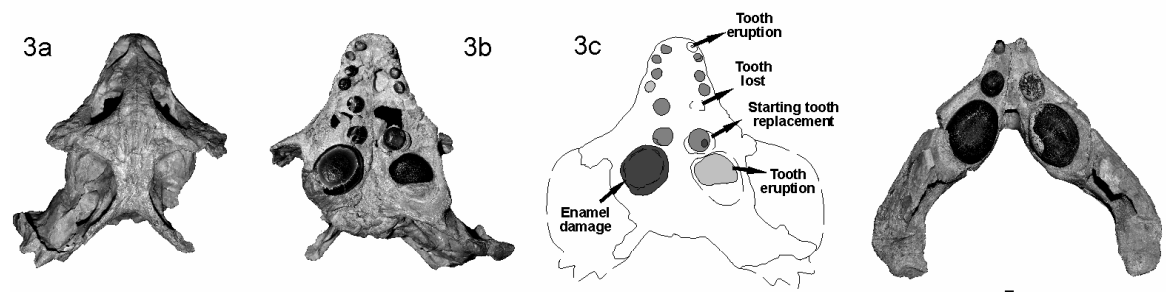

$5 a$

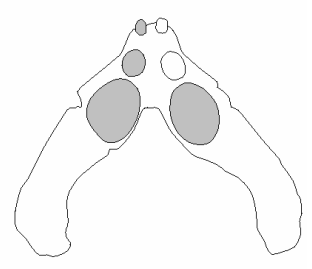

$5 b$
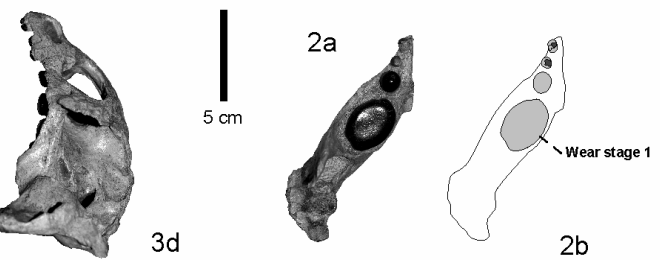

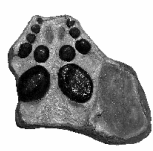

$1 \mathrm{a}$

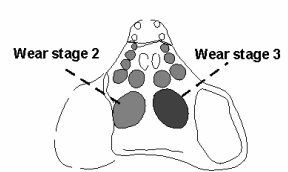

$1 b$

Figure 4. Cyamodus skulls and jaws from the "Upper Muschelkalk" (Anisian, Middle Triassic) from the Germanic Basin (Central Europe). 1. Cyamodus tarnowitzensis Gürich, 1884 holotype skull (cast) from the Karchowice Fm. (Terebratula Member, middle Lower Muschelkalk, lower Pelsonian) of Tarnowice, Poland (SBMF without no.), a-b. ventral, c. lateral. 2. Cyamodus rostratus (Münster, 1839) half lower jaw from the Bindlach Fm. (atavus/pulcher Zone, Illyrian/Fassanian) of Bindlach (Bindlacher Berg, Lainecker Höhenzug), Germany (SBMF no. 4040), dorsal. 3. Cyamodus rostratus (Münster, 1839) holotype skull from the Bindlach Fm. (atavus/pulcher Zone, Illyrian, Upper Anisian) of Bindlach (Lainecker Höhenzug), Germany (UM-O BT 1210a). a. dorsal, b and c. ventral, d. lateral. 4. Cyamodus münsteri (Agassiz, 1839) skull (cast, with completed part dark) of an adult individual from the Bindlach Fm. (atavus/pulcher Zone, Illyrian-Fassanian) of Bindlach (Bindlacher Berg, Lainecker Höhenzug), Germany (SBMF without no., original in the BMNH no. R.1644), a. dorsal, b-c. ventral, d. lateral. 5. Cyamodus rostratus (Münster, 1839) lower jaw from the Bindlach Fm. (atavus/pulcher Zone, Illyrian, Upper Anisian) of Bindlach (Lainecker Höhenzug), Germany (UM-O BT 1210b), a-b. dorsal, c. lateral. 6. Cyamodus kuhnschnyderi Nosotti and Pinna, 1993 holotype skull from the Erfurt Fm. (nodosus to dorsoplanus Zone, Longobardian, Lower Ladinian) of Tiefenbach, Germany (UM-O BT 1210b). a. dorsal, b-c. ventral, d. lateral. 7. Cyamodus kuhnschnyderi Nosotti and Pinna, 1993 lower jaw from the Meissner Fm. (robustus to nodosus Zone, Illyrian/Fassanian, Anisian/Ladinian boundary) of Heldenmühle near Crailsheim, Germany (SNSD 18380), a-b. dorsal. Cyamodus skeleton reconstruction based on the articulated skeleton of $C$. kunhschnyderi from Monte San Giorgio (Switzerland). 
is important to understand placodont reptile evolutionary trends at all.

In Placochelys there are only three skulls from Fassanian to Longobardian to Cordovolian age are available (Figure 5). In the Germanic Basin, some carapace fragments are the only well identified postcranial remains.

2) Facies including palaeocommunities with evidence of macroalgae: Literature studies about marine benthic palaeocommunities and new benthic community studies at the sites Freyburg a. d. U., Bayreuth, Bissendorf and Lamerden are the basics to prove or disprove macroalgae presence/absence in areas of the Germanic Basin, and the north-western Tethys. Studies and literature results for other Germanic Basin and north-western Tethys sites were included to develop three main palaeogeographical maps showing the stages of the Germanic Basin development, which are the basics to understand the presence/absence of placodonts.
3) Bone taphonomy: At the sites Bissendorf, Lamerden, and Bayreuth, but also Winterswijk and many other sites in the Germanic Basin and the Monte San Giorgio sites the relation between facies, skeleton or bone preservation was important to correlate with the facies and palaeocommunity types. A separate study about the Middle Triassic marine reptile bone taphonomy was the base to understand the real possible reptile habitats, their postmortal carcass transport and finally the bonebed accumulation genesis in different palaeoenvironments. Especially the Monte San Giorgio lagoons and skeletons and the shallow marine Germanic Basin ones were compared which both together give a clear picture about the carcass taphonomy stages at all.

4) Osteological and functional morphology: Two original skeletons of Halitherium schinzii (SMNS, and $\mathrm{MB}$ ) from the European Oligocene, were studied for convergence comparisons.

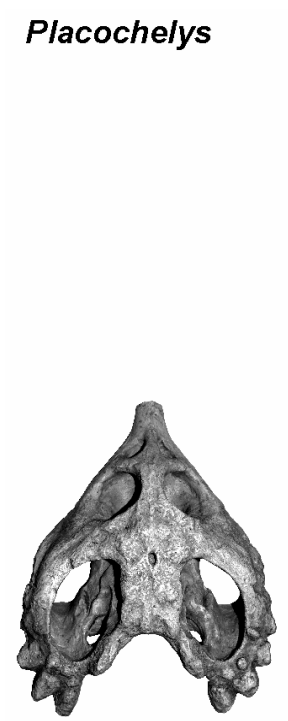

$1 \mathrm{a}$

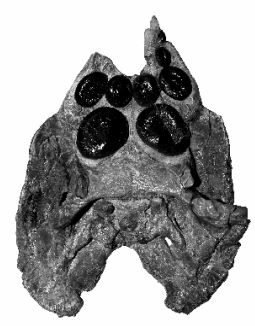

$3 a$

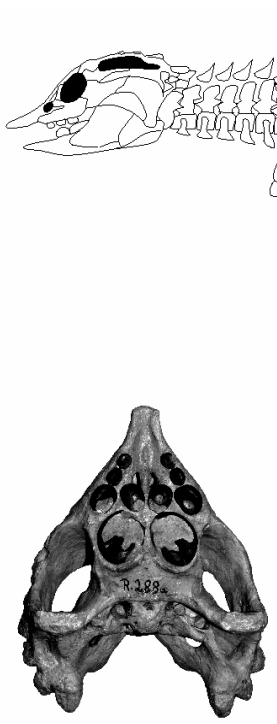

$1 b$

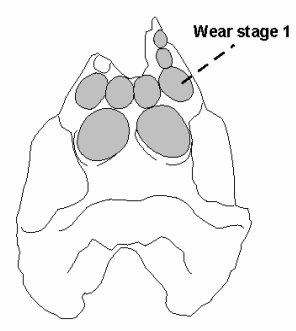

$3 b$

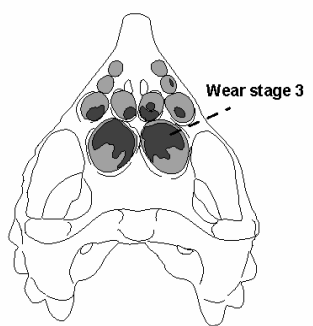

$1 c$
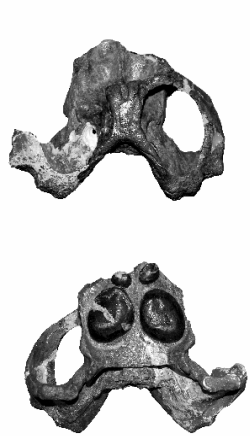

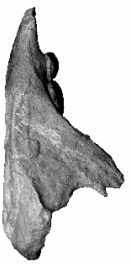

2c

$4 b$

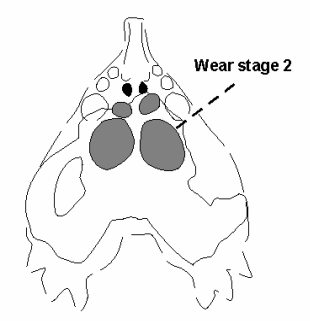

$4 c$

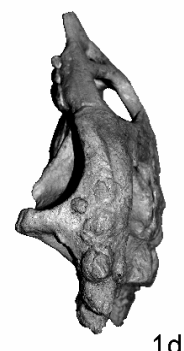

$1 \mathrm{~d}$
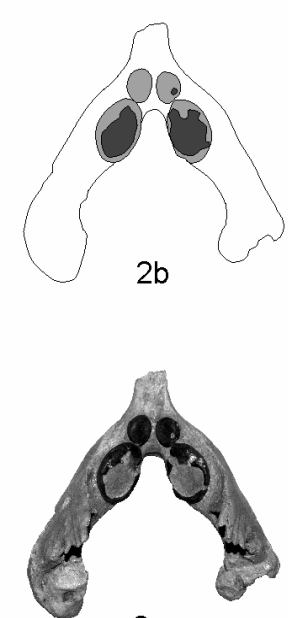

$2 a$

$5 \mathrm{~cm}$

Figure 5. Placochelys placodonta Jaeckel, 1902. Skeleton reconstruction based on the original bones of the holotype skeleton from Hungary. 1. Holotype skull (cast) from the Lower Keuper of Veszprém (Jerusalemer Berg) in Hungary (SBMF no. R.288a). a. dorsal, b-c. ventral, d. lateral. 2. Lower jaw of the holotype skull of Figure 1 (SBMF no. R.288b). a-b. dorsal, c. lateral. 3. Skull from Veszprém (Jerusalemer Berg) in Hungary (MB no. R.1765). a-b. ventral. 4. Skull from the Trochitenkalk Fm. (Illyrian) of Gaismühle near Crailsheim in southern Germany (SNSD no. 17403). Skeleton reconstruction based on the original cranial and postcranial bone material. 


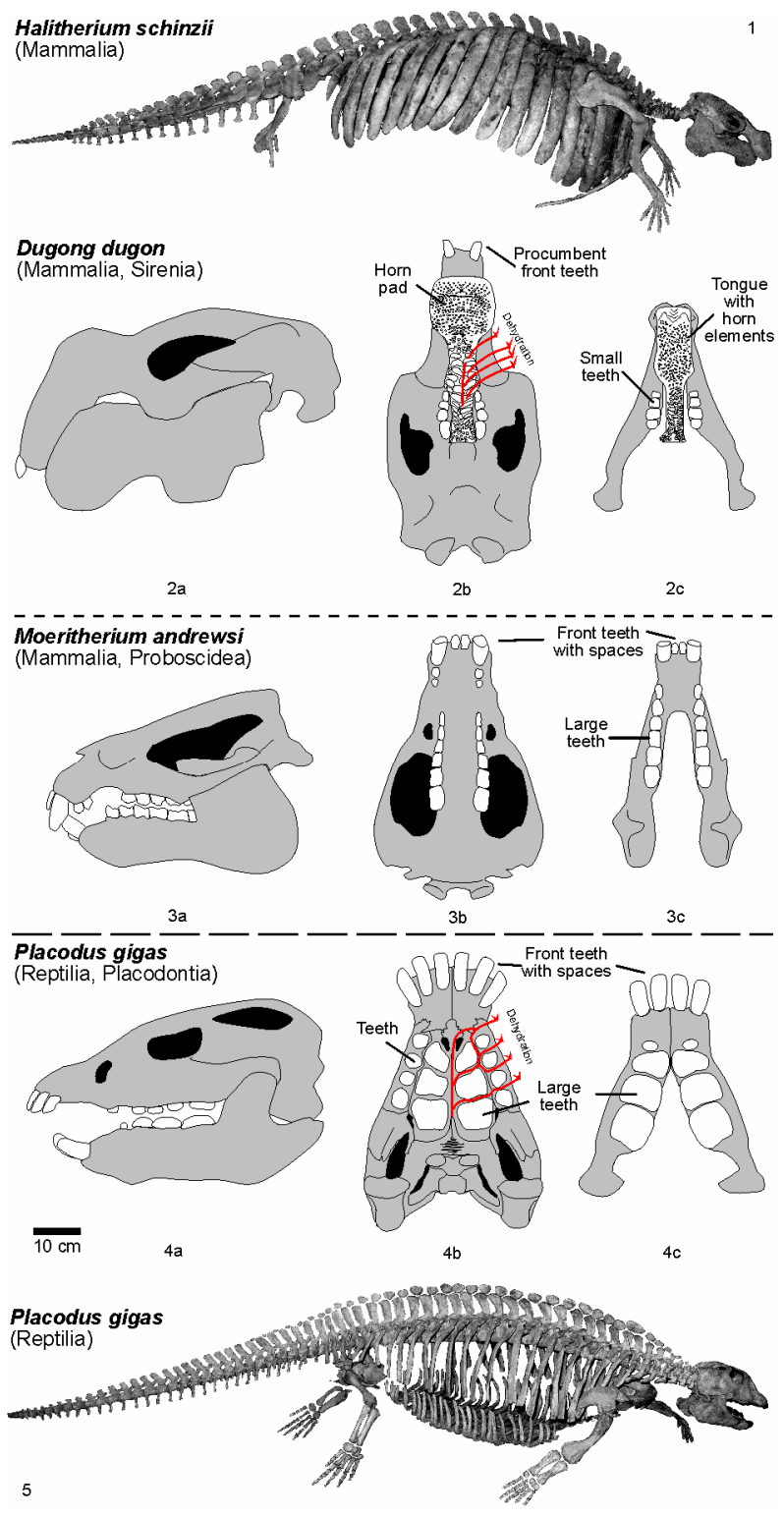

Figure 6. Comparison of osteological convergent development in 1. Halitherium from the Tertiary (Oligocene) of Europe and 2. Modern mammal Dugong and Moeritherium from the European Eocene and 4-5. Placodus from the Middle Triassic of the central European Germanic Basin. (SNSD: Placodus cast, and original Halitherium skeleton. Both skeletons are about 2.5-3.0 meters in length).

5) Feeding strategy in comparison with modern Sirenia: The tooth wear stages in the skulls were analysed as well as the related tooth replacement, for evidence in support of "soft algae" or "shell food" consumption. Axctualistic comparisons were made between Dugong populations in the Arabian Gulf and Placodus populations in the Germanic Basin. The feeding habits and feeding strategy of Dugong was studied to understand the tooth use and possible plant sources Placodus might have fed on.

6) Types of placodont teeth and their tooth wear stages and replacement stages: About 23 Placodus skulls and several lower jaws and the only known original skeleton but also 140 anterior and 420 other teeth, 5 Cyamodus crania and some lower jaws, 3 Placochelys skulls and 1 Paraplacodus skull fragment and postcranial skeleton, but also many lower jaws of those placodonts and, several hundred bones and teeth collected historically from the Germanic Basin of Central Europe were used to understand the tooth replacement in all placodont reptiles.

A palatine of Paraplacodus from Tarnowice ( $\mathrm{Pl})$ shows three different wear stages on the teeth (Figure 2.3). Also the isolated anterior teeth are rubbed on their tips only in one case (Figure 2.2).

From Bayreuth 23 skulls and about 140 anterior and 420 other teeth revealed that almost all of the highly worn teeth were anterior teeth. The other teeth of the maxillaries, palatals or dentaries are in different wear stages in the skulls. In some skulls (Figures $\mathbf{3 . 1}$ and 5) the teeth are all in a similar wear stage 2, in others (Figures 3.3-4) those are in replacement modus, whereas in both this seem to start in the palatine with the posterior paired teeth initially, which are changed first of all six palatal teeth, which is also observed at some other skulls. The skull material gives some insight in possibly more regular way of tooth replacements, but the material is still too few for a statistic and clear picture. Single teeth instead are in $0.5 \%$ in wear stage 1 (Figure 3.7), 99\% are in wear stage 2 (Figure 3.8), and again only $0.5 \%$ are in wear stage 3 (Figure 3.9).

In Cyamodus the tooth change is present in nearly all few skulls (Figure 4), but the material is to few to give a clear tooth change modus. Also here the same three types of wear stages are present. The most interesting skulls of Figures 4.3 and $\mathbf{4 . 6}$ show the tooth replacement at different positions and the erupting replacement teeth. In both skulls it seems, that in the palatals all the two or three teeth of one side are changed first, and then the other side. The postcranial material is few represented in the Germanic basin with some vertebrae and carapace fragments.

In one Placochelys skull all over teeth are in wear stage 1 (Figure 5.3), the second has wear stage 2 in the preserved teeth (Figure 5.3), whereas the third skull has all in wear stage 3 (Figure 5.1). None of the skulls are in any tooth change stages.

The studied placodont skeleton, teeth and bone material is from the following collections: the Senckenbergmuseum Frankfurt (abbreviation: SMF), the Geological Department of Martin-Luther-University, Halle/Saale (abbreviation: MLU.IfG), the Humboldt-Museum of Berlin University (abbreviation: MB), the Staatliche 
Museum für Naturkunde in Stuttgart (abbreviation: SMNS), the Museum für Natur und Umwelt in Osnabrück (abbreviation: NMO), the Urwelt-Museum Oberfranken in Bayreuth (abbreviation: UM-O), the Muschelkalkmuseum in Ingelfingen (abbreviation: MHI), and the Naturkundemuseum in Erfurt (abbreviation: NME). Material from Romania is in the University of Bucharest, non-figured finds from the Dutch site is in the Natural History Museum Enschede or Museum Freriks in Winterswijk.

\section{DISCUSSION}

The cranial material of the Germanic Basin Middle Triassic placodonts Paraplacodus (Figure 2; 5\%), Placodus (Figure 3; 75\%), Cyamodus (Figure 4; 15\%), Placochelys (Figure 5; 5\%) is dominated by Placodus gigas remains. It is here discussed if this is the result of taphonomy or primary habitat differences in the Germanic Basin (e.g. Bayreuth shallow subtidal site) and northwestern Tethys (e.g. Monte San Giorgio lagoon site).

\subsection{Placodont Carcass Taphonomy}

The taphonomical fossil record of placodont remains provides an important source of information on their primary habitats. Paraplacodus was found with a drifted partial skeleton on the Aegean aged intertidal biolaminates of Winterswijk [25], but also in restricted lagoonal black shale facies [7]. Single teeth are from similar layers, in which Placodus and Cyamodus remains were discovered. Placodus and Cyamodus remains, including many isolated bones and teeth, have been found in central Germany, especially in the Lower Muschelkalk "Saurierkalk" of Jena and the Pelsonian "Schaumkalk" carbonate sand bar deposits of Freyburg a. d. U. [34]. Other concentrations come from the Upper Muschelkalk shallow marine terebratulid dominated bioclastic storm shell or glauconitic marl layers of the Illyrian/Fassanian Bindlach and Hegnabrunn Formations near Bayreuth [13] and the Bad Sulza Formation [26], or from recent excavations in sediments of a similar age and terebratulid dominated marginal basin facies at Bissendorf, near Osnabrück in northern Germany [35]. In many cases of isolated placodont teeth those represent in most cases replacement teeth, which were dropped during the animals life explaining the high amount of "black teeth" in the Upper Muschelkalk sediments. The only skeleton to have been found in Germany was of Placodus gigas and came from the Tonplatten facies (Upper Muschelkalk; [20]). In contrast to these shallow marine deposits, placodont bones and teeth are absent from the terrest influenced sediments of the uppermost Upper Muschelkalk bonebeds in northern Germany [13]. This taphonomic distribution therefore provides evidence of a "facies relationship" for these reptile rmains. Placodont bone remains are very abundant in the carbonate sands and bioclastic sediments or shell rich palaeocommunities of the shallow marine shell-rich oolite bar (Lower Muschelkalk) or Terebratulid storm shell facies (Upper Muschelkalk) of the Germanic Basin. In contrast, articulated placodont skeletons from the restricted black shale lagoons of the Swiss and Italian Monte San Giorgio area (AnisianLadinain boundary) appear to represent carcasses, that drifted into the lagoons from their original surrounding habitats of the shallow carbonate platforms [36,37], such as drifted skeletons which were found on intertidal zones in the western Germanic Basin [4]. A few carcasses of terrest coastal living reptiles that were drifted also have been found in the Monte San Giorgio lagoons [37].

\subsection{Osteological Comparisons}

The main arguments for describing placodont reptiles as "Triassic sea cows" that were herbivorous macroalgae feeders derive from their anatomical and osteological similarities to the mammalian Sirenia [1]. A very similar convergence of the body shape in Placodus and the body-weight enhancements of placodonts in general is quite obvious when compared to the European Oligocene siren Halitherium schinzii (see Figure 7). Whereas dugongs developed pachyostotic ribs to enhance their body weight, placodont reptiles achieved a similar result in three different ways: Paraplacodus developed enlarged thoracic ribs; Placodus had pachyostotic thick gastral ribs (Figure 7), and Cyamodus had thoracic osteoderms [1], in the latter similar as in Placochelys or Henodus. Apart from these body shape adaptations for aquatic long-term diving, the skull morphology and dentition provide the most important evidence for convergences. Placodus is very similar in its skull shape to the Oligocene basal proboscidean Meoritherium andrewsi, which was an aquatic animal adapted to feeding on freshwater aquatic plants ([38]; Figure 7). The functional morphology of the horny oral pads of the Sirenia, especially those of the modern Dugong [39], compares well with the dentition of Placodus (Figure 7). The horny oral pads and reduced dentition in trichechiid Sirenia suggest that mouthparts and tongues assumed a major role in food comminution $[40,41]$. The cheek teeth in Modern dugongs are largely non-functional whereas the horny oral pads are important both in the mechanical breakdown of seagrass and in conveying the seagrass through the mouth [40,41]. The full-dentition in the Eocene Protosiren let think about absence of horn pads in early trichiid Sirenia and full function of the lower jaw [42] (Figure 7), which changed to become finally of little importance for dugongs since Oligocene times 


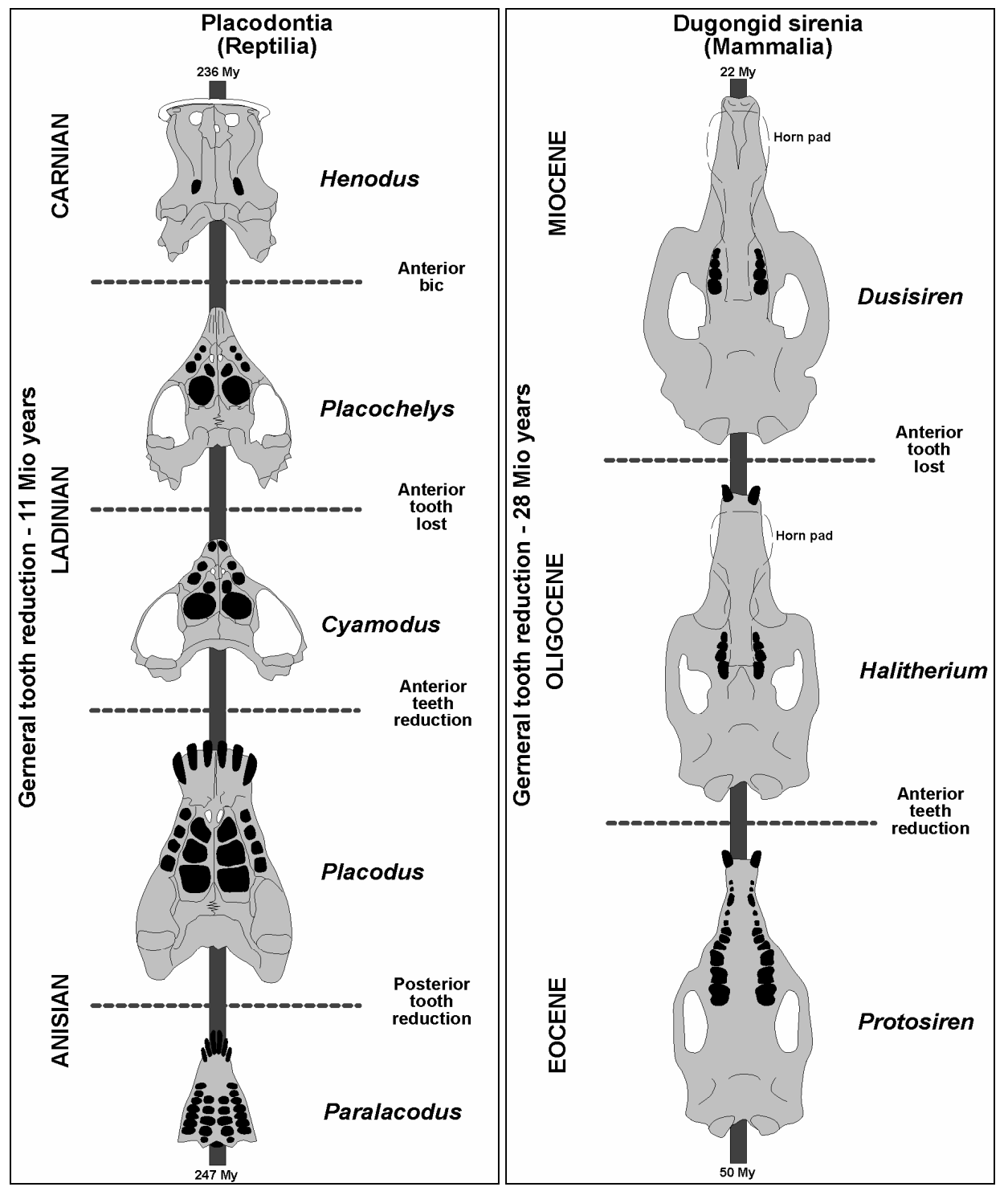

Figure 7. Comparison of convergent long-term development in the tooth reduction of Triassic placodonts (reptiles) and Tertiary sirenia (mammals) as result of adaptation onto seaplant feeding (algae in placodonts, mainly seagrass in dugongs).

(Figure 8). Those lower jaws were certainly more important for Placodus, with its large lower jaw teeth and small tongue. The soft mouthparts of the dugongs are highly modified in the way that the entire oral cavity functions to crush seagrasses and especially the rhizomes, while in the placodonts a similar function was fulfilled by the large teeth that covered the entire jaws. The siren tongue can be seen as convergent in its function to the lower jaws of Placodus (cf. Figure 7). Both, sirens (Dugong) and placodonts (Placodus) have a special orientation of the teeth or horny pads in the upper jaw as another important convergence, apparently developed to facilitate the expulsion of fluids and sand particles during the food-crushing process (cf. Figure 7).
Middle Triassic placodonts Paraplacodus, Placodus, Cyamodus, Placochelys or Henodus and others vary in their morphologies (cf. Figure 7) and their dentition, apparently as a result of specialization on different types of macroalgae, but they still perform similar functions.

\subsection{Palaeocommunities as Macroalgae Indicators Food Source}

There are several indirect lines of evidence for the existence of macroalgae, and even for macroalgae meadows, in the Gemanic Basin within the two facies types of the Jena Fm (Lower Muschelkalk) and the Bad Sulza/ Bindlach/Hegnabrunn and Meissner Fms (Upper 


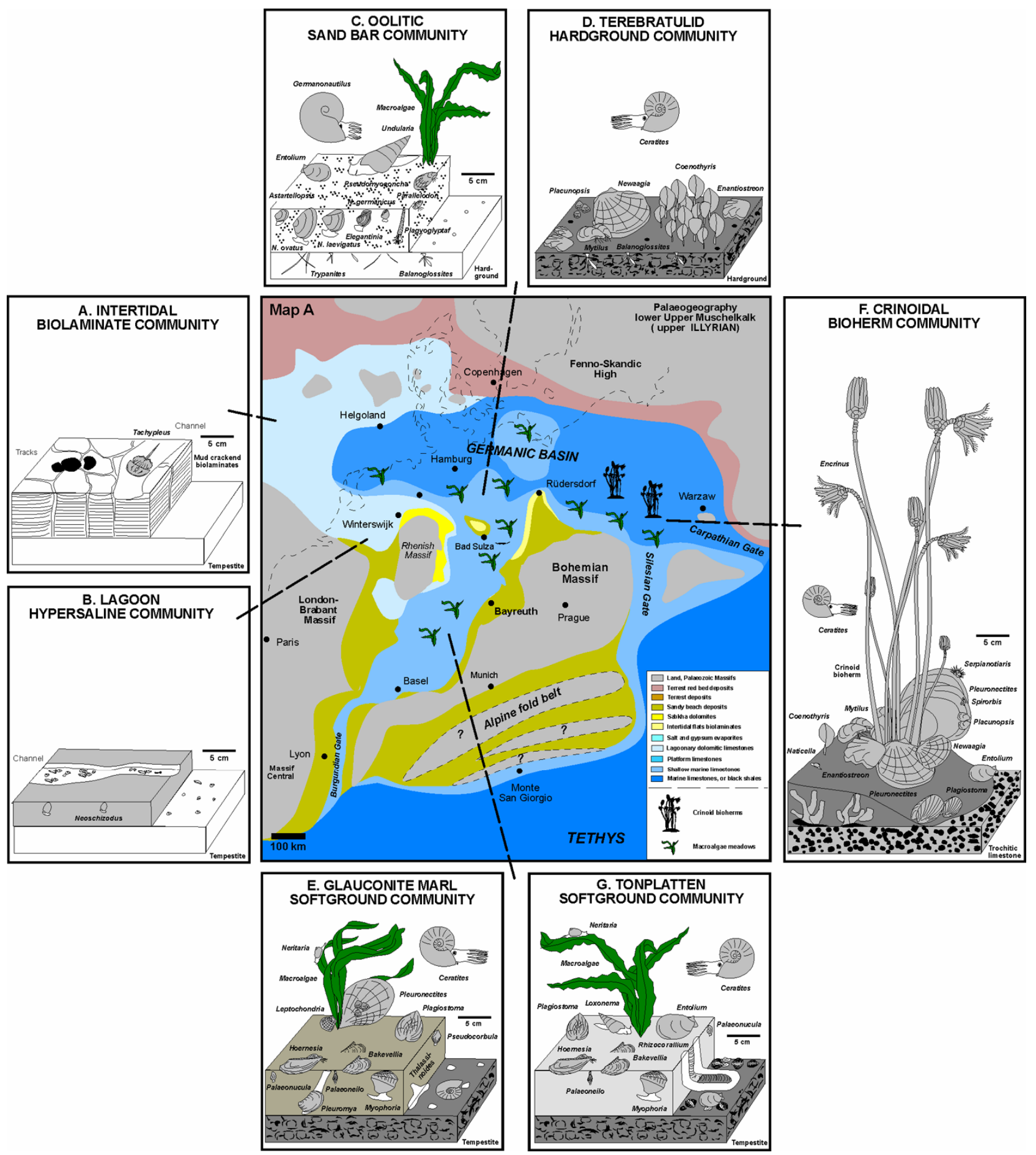

Figure 8. Marine carbonate palaeoenvironments during the Illyrian of Europe (Germanic Basin, north-western Tethys). (Palaeocommunities compiled after: [13]).

Muschelkalk) [40,41], and also in the northern Tethys Cassina Fm (Upper Muschelkalk equivalent) of the Alps ([43]; Figures 8,9). In the "Lower Muschelkalk" benthic communities the gastropod genera Wortheniella, Omphaloptycha and Polygyrina indicate the presence of larger macroalgal meadows $[1,41,44]$. These communities disappeared from the Germanic Basin during the evaporitic Middle Muschelkalk, as did all of the placodonts, whereas bivalves and gastropods that were adapted to hypersaline conditions remained as potential food sources for "du- 
rophagous predators" resisted. During the Upper Muschelkalk of the Germanic Basin benthic communities again provide evidence for the existence of macroalgae in both, the Germanic Basin and the Northern Tethys, with gastropods such as Neritaria in the Germanic Basin [44] and Rhaphistomella and Anoptychia in the Tethys [43] suggesting the existence of extensive macroalgal meadows covering the shallow marine Pangaea surrounding seafloors (Figures 8-10). Their absence of any studies on these possible Middle Triassic macroalgae species is because they have not been preserved as fossils. Other calcareous green algae groups have, however, been documented from shallow marine habitats in the northern Tethys [45], but these algae with their massive calcareous skeletons were most probably not the right plant food-sources for placodonts, but can not be excluded as such. A Placodus skeleton from Middle Triassic lagoonary black shale/carbonate changing Pelsonian strata of the western Tethys lagoons in China [46] has been reported as having no "shell stomach contents", providing further evidence against the "durophagy-thesis", although a larger number of articulated skeletons must be found before this evidence can be considered to be conclusive.

\subsection{Facies Related Palaeobiogeography}

The placodonts Placodus, Cyamodus and Paraplacodus, together with all other Triassic placodonts, very clearly tend to be found in benthic macroalgae palaeoenvironments (Figure 8; [26]), providing additional important support for the hypothesis that placodonts were algae feeders. The reliance on macroalgae as a food source may have been a result of the development of extensive carbonate platform environments around the Pangaean supercontinent at about the time of the transition from Lower to Middle Triassic, which then developed into related carbonate sand facies within the Germanic Basin (Figures 8-10; [35]). This would explain why Placodus, Paraplacodus and Cyamodus had already migrated into these areas by the beginning of the Middle Triassic, as well as explaining the palaeobiogeographic distribution of placodonts in all of the shallow marine shelf paeleoenvironments surrounding Pangaea (Figures 10(a-f)). The Germanic Basin was very different in its palaeoenvironments compared to the north-western Tethys with its lagoons and carbonate platforms. The presence or absence of seaplant food sources must have been the main factor controlling the world-wide distribution of the placodonts during the Middle Triassic, in the same way as the presence or absence of seagrass controls the global distribution of the modern sirenian $D u$ gong [47]. The palaeobiogeography of Triassic placodonts was therefore dependent on the distribution of carbonate sands and bioclastic facies, together with a warm climate, both of which were necessary for extensive growth of macroalgae [48]. Within Europe, various Oligocene species of Sirenia were clearly restricted to these types of habitats, with coincident carbonate sand sea floors and specific vegetation types (algae, seagrass; [37]), even if a few of the the seagrass species have settled more recently on siliciclastic environments.

\subsection{Placodont Tooth Wear Stages and Tooth Replacement Impact}

A study of approximately 140 anterior and 420 other teeth, and 23 skulls, all from Placodus, revealed that almost all of the highly worn teeth were anterior teeth [1]. There are two main problems with the former suggestion that these animals should have been durophagous; firstly, the large spaces between the anterior teeth and, secondly, if shells were consumed the anterior teeth would also be expected to show signs of lateral wear, which was not observed in any of the studied material. Dugongs (Dugong) have procumbent teeth which are also generally worn as a result of their relict function in the excavation of seagrass rhizomes - a function similar to that of the Placodus anterior teeth [49]. Judging by the wear stages of the anterior teeth, the feeding strategy of Placodus must have been very similar to that of modern Sirenia in that the broadly spaced front teeth appear to have been used to dig out macroalgae from the sediments, complete with their roots, rather than to merely strip off macroalgae from the surface. A similar feeding strategy has been observed for modern Dugong feeding on seagrass and, in particular, on its rhizomes which were also excavated from the carbonate sands using the degenerated teeth of their upper jaws [40,41]. The stomach content of an individual female dugong ( $D u$ gong dugon) - which is similar in size to Placodus - had a total dry weight of digesta of about $3,4 \mathrm{~kg}$ of which $98,9 \%$ was seagrass material [50]. The amount of swallowed sediment in the siren stomach was negligible, which is astonishing considering the long, deep trails of feeding depressions that Dugong leave in the sediments $[37,50])$. Dugong have clearly developed a strategy to flush the carbonate sand particles out of their mouths using their mouthparts and adapted tongue [50]. The dentition and jaw functions of placodonts (not only of Placodus) were very similar to those of the modern $D u$ gong, but they used the large teeth that covered the lower and upper jaws instead of horny pads and a specialized tongue to fulfil a similar function removing water or channelling sand from the mouth before swallowing (cf. Figure 6). Chewing of macroalgae was not necessary, and not even possible with the Placodus jaws, as indicated by the very small proportion $(0.5 \%)$ of highly worn palatal, maxillary and dentary teeth with full- 
rubbed enamel. In durophagous animals teeth changements especially of the palatinals and maxillaries would have had strong negative feeding effects with impossibilities to crush well shells. In algae consumers this tooth replacement would have had not that impact. The relatively small overall numbers of worn teeth, mainly estimated on Placodus teeth, are also indicative of a softer diet.

\subsection{Possible Placodont Population Sizes}

Modern dugongs (Dugong dugon) live in large populations ranging between 1,800 and 7,300 individuals in relatively small ocean areas such as the Red Sea or the Arabian Gulf but also in the Indian Ocean [49,51-54]. The Middle Triassic Placodus, at least, may also have been present in somewhat smaller, but still large populations, as estimated from the relatively large numbers of bones and teeth found all over Europe and especially in Germany. In some bonebeds several placodont teeth and bones have been found within only a few square meters in a single layer [35]. Although the large quantities of Placodus, and fewer Cyamodus, and to a lesser extent, Paraplacodus bones and teeth in the "Jenaer Saurierkalk" (Lower Muschelkalk) and the "Bayreuther Muschelkalk" (Upper Muschelkalk) of the Germanic Basin would certainly have accumulated over long periods of time (Figures 9,10), they nevertheless appear to support the speculative existence of Placodus populations comprising between several hundred and several thousand individuals within the Germanic Basin, with smaller populations of Cyamodus or other placodonts, even if taken in account, that many isolated teeth are replacement teeth.

\subsection{Palaeobiogeography and Evolutionary Trends}

In the Germanic Basin the ratio between the Middle Triassic placodonts is estimated on the studied material (Bones/Teeth $=1,257$ specimens): Placodus (75\%), Cyamodus (20\%), Paraplacodus (5\%). In the lagoons of the northwestern tethys (Monte San Giorgio) the fossil record of those three placodonts is completely different: Placodus (1\%), Cyamodus (70\%), Paraplacodus (29\%). Especially the presence and nearly absence of Placodus is the best argument for the adaptation onto macroalgae feeding, because those algae were absent in the lagoons of the Monte San Giorgio [45], which finally explains also the absence of Placodus there (cf. Figures 9,10). Placodus gigas seems to have been well distributed within the Germanic Basin since the marine ingression at the top of the Lower Triassic (Myophoria/Gogolin Members, Upper Bunter: [1,34] (Figure 10(a)), and few remains from the northern Tethys (?Israel; [3]) indicate that an interchange of these reptiles must have been present during the basal Middle Triassic. A new Placodus skeleton has, however, recently been reported from the Pelsonian of China [46]. Paraplacodus broilli (Peyer, 1931) remains from the uppermost Upper Bunter (Aegean) to upper Lower Muschelkalk (Pelsonian) of the Germanic Basin indicate a similarly early presence and continuing existence [25], and range to the middle Upper Muschelkalk with a skeleton find in the Monte San Giorgio lagoon deposits from the Anisian/Ladinian boundary [7] (Figures 9, 10(d)). In the material from both of these species no (or few not yet recognized) evolu- tionary development can be observed over almost the whole of the Middle Triassic (Aegean to Fassanian, 247- $239 \mathrm{My}$ ); this may, however, possibly be due to gaps in the fossil record. In contrast, Cyamodus shows an evolu- tionary trend in general tooth reduction during the Mid- dle Triassic (Figure 9). This form of tooth reduction, which also occurred in the Sirenia during the Tertiary, can be seen in both Cyamodus and generally in all pla- codonts (Figure 9).

The oldest Cyamodus records in the Germanic Basin are of Cyamodus tarnowitzensis from the Myophoria/ Gogolin Members (Lower/Middle Triassic boundary). This species then dissappeared during the Middle Muschelkalk low stand, together with all other placodonts (Figure 9). C. rostratus then appeared with a new transgression into the Germanic Basin. C. hildegardis, which already had fewer praemaxillary and maxillary teeth, became distributed within the Germanic Basin, and also in the north-western Tethys where the only known skeleton was found [6] in the lagoonal deposits of Monte San Giorgio [1]. These cyamodonts were able to migrate and spread out to the north and south during the maximum high stand, and were not "endemic" species, in contrast. Finally, skulls of Cyamodus kuhnschyderi have been found in the Burgundian Gate and Germanic Basin regions [28]. During the upper Ladinian the marine environment of the Germanic Basin became brackish and a lagoon until it finally disappeared, as did all of the placodonts. In the meantime, other placodont genera (Macroplacus, Protenodontosaurus, Psephoderma: Jaeckel, $1907[2,3,33,55]$ developed from these or other related placodonts in the shallow marine north-western Tethys over a long time frame of about $30 \mathrm{My}$ (chronostratigraphy: [56]; Figure 9), although their global distribution, palaeobiogeography, and systematic relationships still remain unclear as a result of the scarcity of the fossil record.

Similar trends to the tooth reduction within Triassic placodonts (Figure 7) have also been reported in the evolution of mammalian Sirenia [38] presented here for Tertiary Protosiren, Halitherium and Dusosiren [37,42, 57]. Both, the early placodonts and early Sirenia, were 


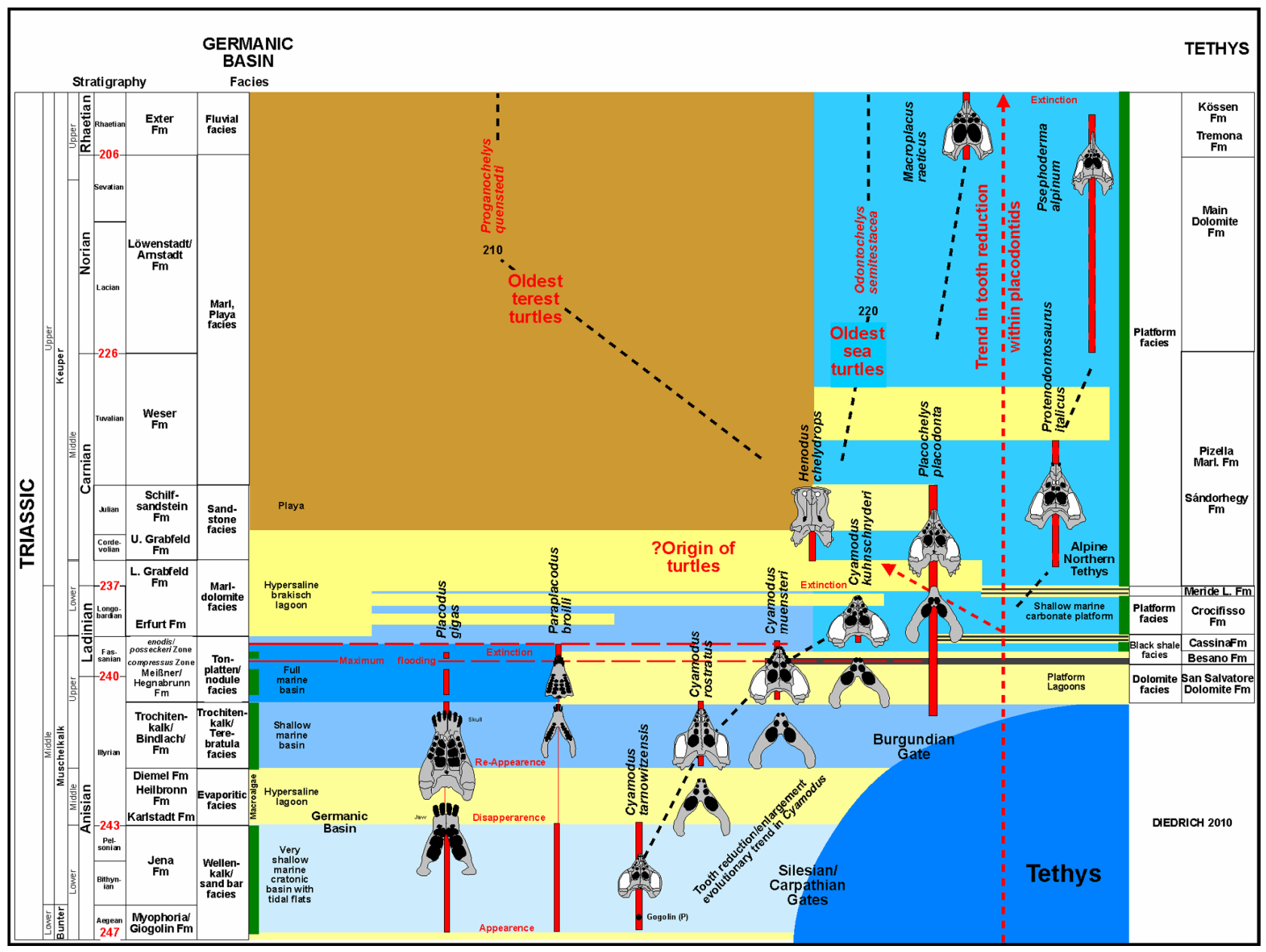

Figure 9. Palaeoenvironmental relationships of placodonts and evolutionary trends in Europe (Germanic Basin, north-western Tethys). (Skulls compiled and redrawn from: [1,3,5,23,27-30,31,43,55,58]).

therefore in the early evolutionary stages of animals adapting to feeding on aquatic seaplants. At the other extreme, Henodus $[58,59]$ whose systematic position is unclear but is believed to be closest to Cyamodus [3], represents the "final stage" of tooth reduction with only a single tooth remaining in its skull and horny ridges similar to those developed in turtles. In terms of the "macroalgae feeding" evolutionary trend Henodus was the most evolved, possibly even sometimes feeding on jellyfish (as do turtles) during the Lower Keuper (Carnian) when macroalgae in the Germanic Basin lagoon facies were likely to have been either completely absent or reduced to only a few specialized species. Possibly Placochelys and Henodus also developed possibly horny pads, which can not be proven anatomically yet. New discoveries of cyamodonts from China, such as Psephochelys polyosteoderma (Chun and Rieppel, 2002) [60], and other remains of uncertain origin from the northern Tethys [61], demonstrate the incompleteness of our knowledge of their phylogeny, particularly with re- gard to the Upper Triassic fossil record.

The tooth reduction evolutionary trend in placodonid reptiles is illogical in the context of the previously suggested "durophagy", but can instead be logically explained as being a result of the adaptation to macroalgal plant feeding that started somewhere on the shallow marine carbonate platforms surrounding Pangaea during the Lower Triassic (Figures 9, 10(a)). It may even offer an explanation for the "origin of turtles" - in a similar manner to the Henodus lineage - as toothless primary algae and secondary jelly fish consumers that eventually developed into terrestrial turtles such as the globally distributed Norian Proganochelys (Gaffney, 1990) [62], and marine sea-turtles $[8,63]$ such as the Carnian Odontochelys [8] of the western Tethys, from a starting point in the Longobardian (or even earlier in the Fassanian), when the palaeogeography of the shallow marine habitats surrounding Pangaea went through dramatic changes with extended shallow marine habitat disappearances (Figures 9,10(e-f)). 



Figure 10. Palaeobiogeography of placodonts in Europe (Germanic Basin, north-western Tethys). 
The long period of turtle evolution [64] might be explained also as a result of these studies on placodonts. All those reptiles may have fed on macroalgae already in the Middle Triassic and even earlier up to Late Triassic, but changes to the distribution of shallow marine areas $[44,45,56,64]$ and the conditions within them (Figures

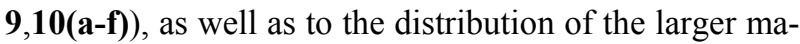
rine basins that formed their habitats within the Germanic Basin [37], all seem to have played a major role in furthering the evolution of the placodonts, and also of the marine and terrestrial turtles that today are toothless plant feeders and, to a lesser extent, jellyfish consumers.

\section{RESULTS}

The sauropterygian marine placodont reptile evolution and diversification around Pangaea seem to have its origin already in the upper Lower Triassic and reached after 11 My (247-236 My) its extinction. Those former believed "durophagous" divers are presented here as macroalgae sea plant eating adapted reptiles (Figures 11(a-d)), which were convergent developed in their body shape and jaw function very close to such as siren mammals, which evolved during the Tertiary in similar ways by enhancing their body weights for long-term- diving and reducing of their dentition to adapt onto seaplant feeding. Whereas Triassic placodonts Paraplacodus (Figure 11(a)), Placodus (Figure 11(b)), Cyamodus (Figure 11(c)), or Placochelys (Figure 11(d)), lived in macroalage meadow shallow marine carbonate palaeoenvironments in the Germanic Basin and northern Tethys, extinct Tertiary or Modern Sirania such as Halitherium or Dugong fed and feed on seagrass in similar environments. The placodonts were distributed already within the late Lower Triassic around Pangaea and emigrated at the Aegean (lowermost Anisian) time into the marine developing Germanic Basin, whereas their distribution was depend on shallow marine carbonate platform environments surrounding the Tethys Ocean, and its marginal basins. Those habitats changed drasticcally within the Triassic, whereas an intracratonic Germanic Basin as a main habitat became extinct within the Late Triassic, and with this the placodonts. As a possible reaction of the marine habitat extinction and new hypersaline lagoon developments at the Middle/Upper Triassic in the Germanic Basin and northern Tethys those environmental changes seem to have been the main reason for the development from placodonts or to placodonts parallel evolution of turtles, which are already nearly

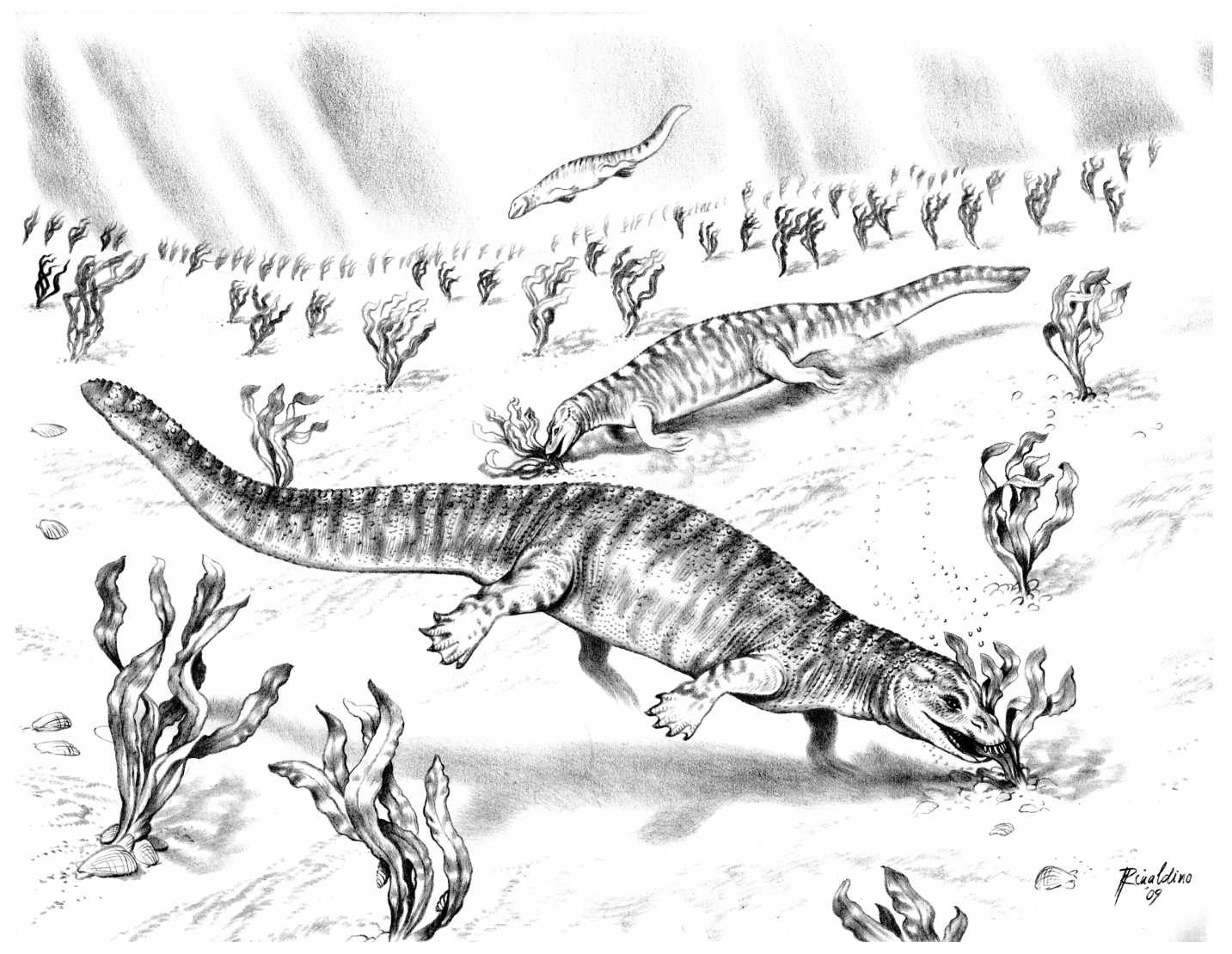

(a) 


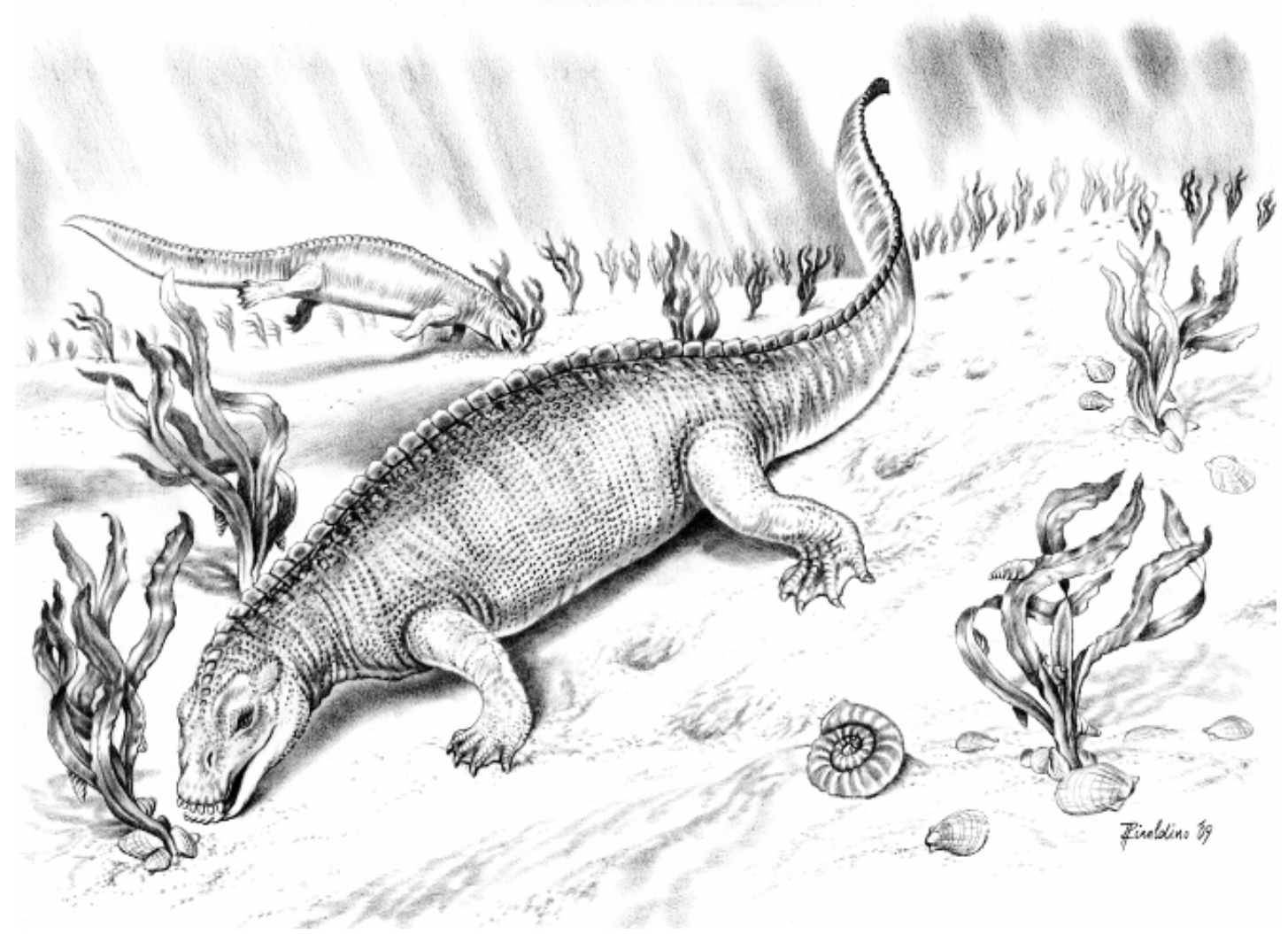

(b)

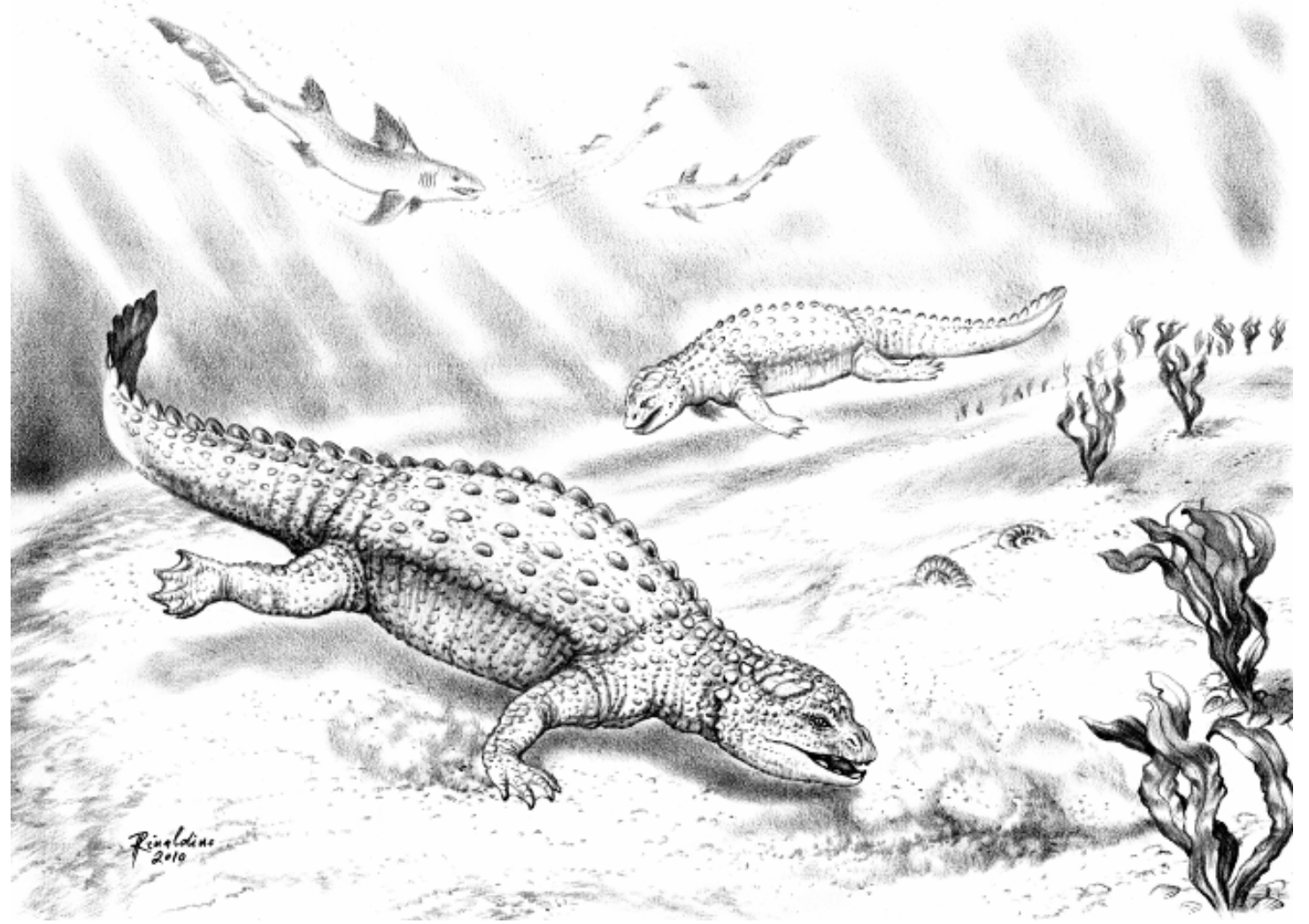

(c) 


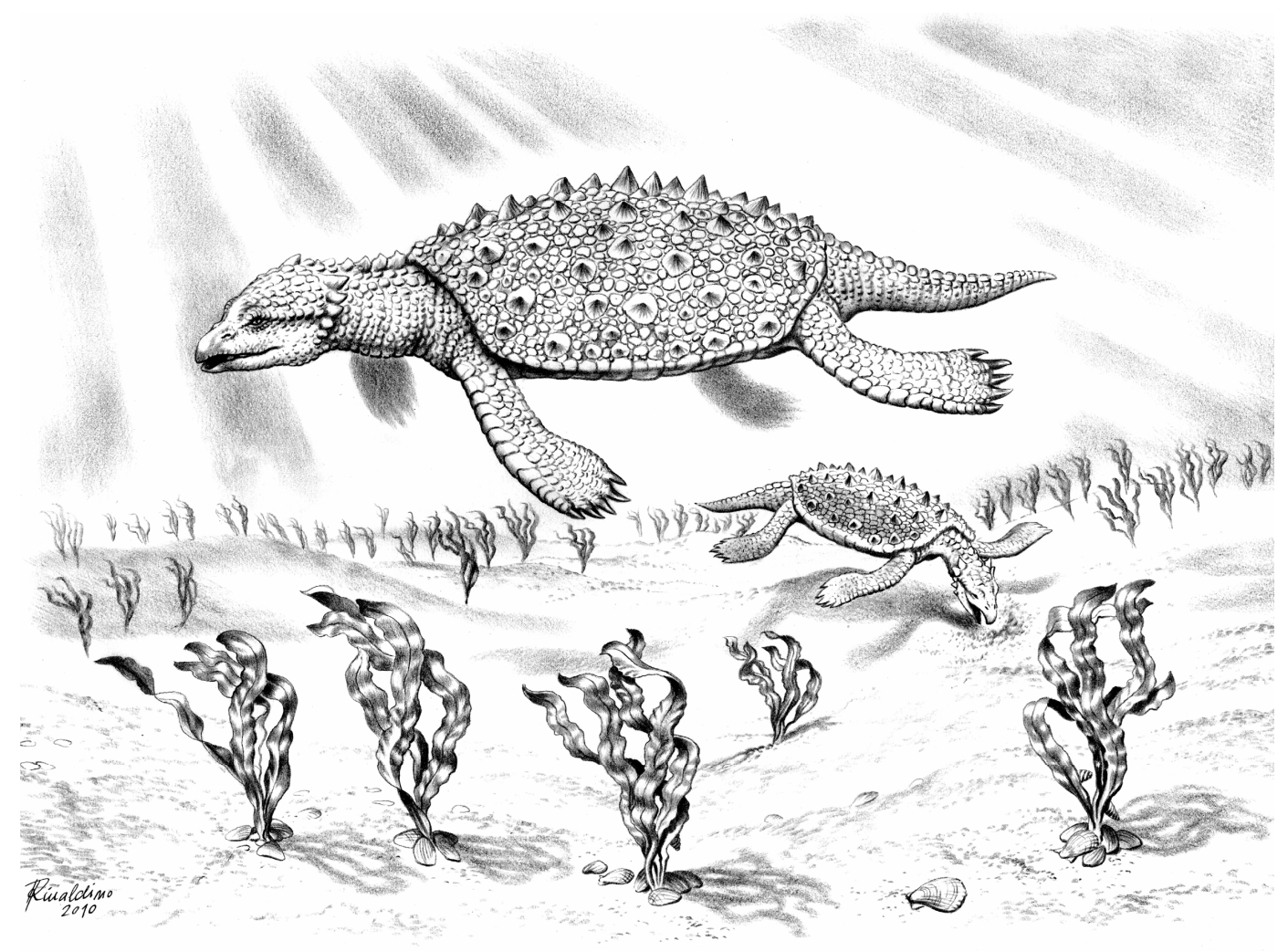

(d)

Figure 11. (a) Paraplacodus, (b) Placodus, (c). Cyamodus and (d) Placochelys during the Middle Triassic (Illyrian-Longobardian) Upper Muschelkalk/Lower Keuper in the Germanic Basin as specialized macroalgae feeders (Illustrations "Rinaldino"- G. Teichmann).

toothless in the early Late Triassic, an adaptation similar onto algae and possibly even jellyfish consuming, and end of tooth reduction trend.

\section{ACKNOWLEDGEMENTS}

I thank many museums and their curators (Senckenbergmuseum Frankfurt, Naturkundemuseum Osnabrück, Naturkundemudeum Magdeburg, Lippisches Landesmuseum Detmold, Humboldt-Museum of Berlin University, Staatliche Museum für Naturkunde Stuttgart, Museum für Natur und Umwelt Osnabrück, Urgeschichtliche Museum Bayreuth, Muschelkalkmuseum Ingelfingen, and Naturkundemuseum Erfurt) and research institutions (Martin-Luther-University Halle/Saale) for their collections access and support. The reptile illustrations are produced with copyrights for the company PaleoLogic (www.paleologic.de) by G. "Rinaldino" Teichmann, the spelling and general check of the first manuscript was made by E. Manning.

\section{REFERENCES}

[1] Diedrich, C. (2009b) The vertebrates of the Anisian/ Ladinian boundary (Middle Triassic) from Bissendorf (NW Germany) and their contribution to the anatomy, palaeoecology, and palaeobiogeography of the Germanic
Basin reptiles. Palaeogeography Palaeoclimatology Palaeoecology, 273, 1-16. doi:10.1016/j.palaeo.2008.10.026

[2] Jaeckel, O. (1907) Placochelys placodonta aus der Obertrias des Bakony. Resultate der wissenschaftlichen Erforschung des Balaton, 1, 1-90.

[3] Rieppel, O. (2000) Sauropterygia I. Placodontia, Pachypleurosauria, Nothosauroidea, Pistosauroidea. Handbuch der Paläoherpetologie, Teil 12A. München, Friedrich Pfeil.

[4] Oosterink, H.W., Berkelder, W., Jong, C., de Lankamp, J. and Winkelhorst, H. (2003) Sauriens uit de OnderMuschelkalk van Winterswijk. Staringia, 11, 1-145.

[5] Kuhn-Schnyder, E. (1960) Über Placodontier. Paläontologische Zeitschrift, 34, 91-102.

[6] Peyer, B. (1931a) Die Triasfauna der Tessiner Kalkaplen, III: Placodontia. Abhandlungen der Schweizerischen Paläontologischen Gesellschaft, 51, 1-25.

[7] Peyer, B. (1931b) Paraplacodus broilii nov. gen. nov. spec., ein neuer Placodontier aus der Tessiner Trias. Verhandlungen der Schweizerischen Naturforschenden Gesellschaft, 109, 1-219.

[8] Chun, L., Wu X.-C., Rieppel, O., Wang, L.T. and Zhao, L.Z. (2008) An ancestral turtle from the Late Triassic of southwestern China. Nature, 456, 497-501. doi:10.1038/nature 07533

[9] Münster, G.G. (1830) Über einige ausgezeichnete fossile 
Fischzähne aus dem Muschelkalk bei Bayreuth: Bayreuth, Birner.

[10] Agassiz, L. (1833-1843) Recherches sur les Poissons fossiles: Neuchatel et Soleure.

[11] Weiß, G.W. (1937) Bayreuth als Stätte alter erdgeschichtlicher Entdeckungen: Bayreuth. Gauverlag Bayerische Ostmark GmbH.

[12] Owen, R. (1858) Description of the skull and teeth of the Placodus laticeps Owen with indications of other new species of Placodus and evidence of the saurian nature of that genus. Philosophical Transactions of the Royal Society London, 148, 169-182. doi:10.1098/rstl.1858.0009

[13] Diedrich, C. (2011) Palaeoenvironment, stratigraphy, facies and biodiversity of the marine reptile-rich Middle Triassic carbonates of the famous Bayreuth localities (Germany) in the Germanic Basin of Europe. (in review).

[14] Braun, C.W.F. (1862) Über Placodus gigas Agassiz und Placodus andriani Münster. Programm zum Jahresbericht der königlichen Kreis-Landwirtschafts- und Gewerb eschule zu Bayreuth für das Schuljahr 1861/62. Bayreuth, Theodor Burger.

[15] Braun, C.W.F. (1863) Über Placodus quinimolaris. Programm zum Jahresbericht der königlichen KreisLandwirtschafts- und Gewerbeschule zu Bayreuth für das Schuljahr 1862/63. Bayreuth, Theodor Burger.

[16] Meyer, H. von (1863b) Placodus andriani aus dem Muschelkalk der Gegend von Braunschweig. Palaeontographica, 10, 57-61.

[17] Meyer, H. von (1847-1855) Zur Fauna der Vorwelt. 2 Abt. Die Saurier des Muschelkalkes mit Rücksicht auf die Saurier aus Buntem Sandstein und Keuper..Frankfurt a. Main.

[18] Meyer, H. von (1863a) Die Placodonten, eine Familie von Sauriern der Trias. Palaeontographica, 11, 175-291.

[19] Broili, F. (1912) Zur Osteologie des Schädels von Placodus. Palaeontographica, 59, 147-155

[20] Drevermann, F. (1924) Schädel und Unterkiefer von Cyamodus. Abhandlungen der senckenbergischen naturforschenden Gesellschaft, 38, 291-309.

[21] Drevermann, F. (1933) Das Skelett von Placodus gigas Agassiz. Abhandlungen der senckenbergischen naturforschenden Gesellschaft, 38, 321-364.

[22] Huene, F. von (1933) Zur Lebensweise und Verwandtschaft von Placodus. Abhandlungen der senckenbergischen naturforschenden Gesellschaft, 38, 367-382.

[23] Diedrich, C. (2010a) Palaeoecology of Placodus gigas (Reptilia) and other placodonts - Middle Triassic macroalgae feeders in the Germanic Basin of central Europe and evidence for convergent evolution with Sirenia. $\mathrm{Pa}$ laeogeography Palaeoclimatology Palaeoecology, 285, 287-306.

[24] Nosotti, S. and Pinna, G. (1996) Osteology of the skull of Cyamodus kuhnschnyderi n. sp., novelle espèce de Cyamodontidae (Reptilia, Placodontia) du Muschelkalk supérieur allemande. Comptes Rendues de l'Academie de Sciences Paris, 317, 847-850.

[25] Rieppel, O. and Hagdorn, H. (1999) A skull of Cyamodus kuhnschnyderi Nosotti \& Pinna 1993, from the Muschelkalk of wasselonne (Alsace, France). Paläontolo gische Zeitschrift, 73, 377-383.

[26] Kuhn, O. (1969) Subclass Placodontomorpha Kuhn 1968.
Handbuch Palaeoherpetologie, 9, 7-18.

[27] Suess, H.D. (1987) On the skull of Placodus and the relationships of the Placodontia. Journal of Vertebrate Paleontology, 7, 138-144.

[28] Rieppel, O. (1995) The Genus Placodus: Systematics, Morphology, Paleobiogeography, and Paleobiology. Fieldiana Geology NS, 31, 1-44.

[29] Westphal, F. (1988) Pflasterzahnsaurier (Placodonten) aus dem süddeutschen Muschelkalk (Mitteltrias). In: Hagdorn, H. (ed.), Neue Forschungen zur Erdgeschichte von Crailsheim. Muschelkalk. Schöntaler Symposium. Goldschneck-Verlag, Stuttgart, 151-165.

[30] Rieppel, O. and Zanon, R.T. (1997) The interrelationships of placodontia. Historical Biology, 12, 211-227.

[31] Diedrich, C. and Trostheide, F. (2007) Auf den Spuren der terresten Muschelkalksaurier und aquatischen Sauropterygier vom obersten Röt bis zum Mittleren Muschelkalk (Unter-/Mitteltrias) von Sachsen-Anhalt. Abhandlungen und Berichte zur Naturkunde Magdeburg, 30, 5-56.

[32] Diedrich, C. (2009a) Palaeogeographic evolution of the marine Middle Triassic marine Germanic Basin changements - with emphasis on the carbonate tidal flat and shallow marine habitats of reptiles in Central Pangaea. Global and Planetary Change, 65(2009), 27-55.

[33] Diedrich, C. (2008a) Millions of reptile tracks - Early to Middle Triassic carbonate tidal flat migration bridges of Central Europe. Palaeogeography, Palaeoclimatology, Palaeoecology, 259, 410-423.

[34] Diedrich, C. (2008b) The food of the miosiren Anomotherium langenwieschei (Siegfried) - indirect proof of seaweed or seagrass by xenomorphic oyster fixation structures in the Upper Oligocene (Neogene) of the Doberg, Bünde (NW Germany) and comparisons to modern Dugong dugon (Müller) feeding strategies. Senckenbergiana maritima, 38, 59-73.

[35] Thenius, E. (1979) Die Evolution der Säugetiere. Stuttgart-New York, Gustav Fischer Verlag.

[36] Marsch, H. and Eisentraut, M. (1984) Die Gaumenfalten des Dugong. Zeitschrift für Säugetierkunde, 49, 314-315.

[37] Lanyon, J.M. and Sanson, G.D. (2006a) Degenerate dentition of the dugong (Dugong dugon), or why a grazer does not need teeth: morphology, occlusion and wear of mouthparts. Journal of Zoology, 268, 133-152. doi:10.1111/j.1469-7998.2005.00004.x

[38] Lanyon, J.M. and Sanson, G.D. (2006b) Mechanical disruption of seagrass in the digestive tract of the dugong. Journal of Zoology, 270, 277-289.

[39] Domning, D.P. (1978) Sirenian evolution in the North Pacific Ocean. University of California. Geological Sciences, 118, 1-176.

[40] Fürsich, F.T. (1981) Die Palaeonucula strigilata/Dentalium undulatum-Faunengemeinschaft in Weichböden der mittleren alpinen Trias. In: McKerrow, W.S. (ed.), Paläoökologie: Stuttgart, Franckh, 138-139.

[41] Hagdorn, H. (2004) Muschelkalkmuseum Ingelfingen. Edition Lattner.

[42] Furrer, H. (1993) Stratigraphie und Fazies der Trias/ Jura-Grenzschichten in den Oberostalpinen Decken Graubündens. Dissertation University Zürich.

[43] Yiang, D.-J., Motani, R., Hao, W.-C., Rieppel, O., Sun, Y.-L., Schmitz, L. and Sun, Z.-Y. (2008) First Record of 
Placodontoidea (Reptilia, Sauropterygia, Placodontia) from the Eastern Tethys. Journal of Vertebrate Paleontology, 28, 904-908. doi:10.1671/0272-4634(2008)28[904:FROPRS]2.0.CO;2

[44] Domning, D.P. (2001) Sirenians, seagrasses, and Cenozoic ecological change in the Caribbean. Palaeogeography Palaeoclimatology Palaeoecology, 166, 27-50. doi:10.1016/S0031-0182(00)00200-5

[45] Aysel, V., Erdugan, H. and Okudan, E.Ş. (2006) Marine Algae and Seagrasses of Hatay (Mediterranean, Turkey). Journal of the Black Sea Meditteranean Environment, 12, 159-179.

[46] Domning, D.P. and Beatty, B.L. (2007) Use of Tusks in Feeding by Dugongid Sirenians: Observations and Tests of Hypotheses. Anatomic Record, 290, 523-538. doi:10.1002/ar.20540

[47] Erftemeijer, P.L.A., Djunarlin, M. and Mok, W. (1993) Stomach content analysis of a Dugong (Dugong dugon) from South Sulawesi, Indonesia. Australian Journal of Marine and Freshwater Research, 44, 229-233.

[48] Gohar, H.A.F. (1957) The Red Sea dugong. Marine Biological Station Al-Ghardaqa Red Sea, 9, 3-49.

[49] Reynolds, J.E. and Odell, D.K. (1991) Manatees and Dugongs. New York.

[50] Marsch, H. (2002) Dugong-Status Report and Action Plans for Countries and Territories. Nairobi: United Nations Evironment Programme, DEWA, RS.02.

[51] Ripple, J. (2002) Manatees and Dugongs of the World: Hong-Kong, Voyageur Press.

[52] Schubert-Klempnauer, H. (1975) Macroplacus raeticus n.g., n. sp. ein neuer Placodontier aus dem Rät der Bayrerischen Alpen. Mitteilungen der Bayrischen Staatssammlung für Paläontologie und Historische Geologie, 15, 33-55.

[53] Kozur, H.W. and Bachmann, G.H. (2008) Updated correlation of the Germanic Triassic with the Tethyan scale and assigned numeric ages. Berichte der Geologischen Bundesanstalt Wien, 76, 53-58.

[54] Gingerich, P.D., Domning, D.P., Blane, C.E. and Uhen, M.D. (1994) Cranial morphology of Protosiren fraasi
(Mammalia, Sirenia) from the middle Eocene of Egypt: a new study using computed tomography. Contributions from the Museum of Paleontology, University of Michigan, 29, 41-67.

[55] Huene, F. von (1936). Henodus chelydrops, ein neuer Placodontier. Palaeontographica A, 84, 99-147.

[56] Reif, W. (1942) Ergänzungen zum Panzerbau von Henodus chelydrops v. Huene. Palaeontographica A, 94, 31-42.

[57] Chun, L. and Rieppel, O. (2002) A new cyamodontoid placodont from Triassic of Guizhou, China. China Science Bulletin, 47(5), 403-407. doi: $10.1360 / 02 \mathrm{tb} 9094$

[58] Buffeteaut, E. and Novak, M.A. (2008) Cyamodontid placodont (Reptilia: Sauropterygia) from the Triassic of Slovenia. Palaeontology, 51, 1301-1306. doi:10.1111/j.1475-4983.2008.00819.x

[59] Gaffney, E.S. (1990) The comparative osteology of the Triassic turtle Proganochelys. Bulletin of the American Museum of Natural History, 194, 1-263.

[60] Reisz, R.R., Jason, J. and Head, J.J. (2008) Palaeontology: Turtle origins out to sea. Nature, $\mathbf{4 5 6}, 450-451$. doi: $10.1038 / 456450 \mathrm{a}$

[61] Scheyer, T.M. (2008) Aging the oldest turtles: The placodont affinities of Priscochelys hegnabrunnensis. Naturwissenschaften, 95, 803. doi:10.1007/s00114-008-0386-8

[62] Aigner, T. and Bachmann, G.H. (1991) Sequence Stratigraphy of the German Muschelkalk. In: Hagdorn H, Seilacher, A. (eds). Muschelkalk, Schöntaler Symposium. Goldschneck-Verlag, Stuttgart, 15-18.

[63] Haas, J. and Budai T. (1999) Triassic sequence stratigraphy of the Transdanubian range. Geologica Carpathica, 50, 459-475. doi:10.1556/AGeol.45.2002.1.3

[64] Nagy, Z.R. and Csillag, G. (2002) Correlation of Upper Julian to Lower Tuvalian (Carnian) depositional cycles from the Balatonhenye. Barnag area, Balaton Highland, Hungary. Acta Geologica Hungaria, 45, 45-62. 